\title{
Mafic rocks of the Ordovician Famatinian magmatic arc (NW Argentina): New insights into the mantle contribution
}

\author{
P.H. Alasino ${ }^{1,2, \dagger}$, C. Casquet ${ }^{3}$, R.J. Pankhurst ${ }^{4}$, C.W. Rapela ${ }^{5}$, J.A. Dahlquist ${ }^{6}$, C. Galindo ${ }^{3}$, M.A. Larrovere Lat, $^{1,2}$ \\ C. Recio ${ }^{7}$, S.R. Paterson ${ }^{8}$, F. Colombo ${ }^{6}$, and E.G. Baldo ${ }^{6}$ \\ ${ }^{1}$ Centro Regional de Investigaciones Científicas y Transferencia Tecnológica de La Rioja (CRILAR)-Consejo Nacional de \\ Investigaciones Científicas y Técnicas (CONICET), Entre Ríos y Mendoza, 5301, Anillaco, La Rioja, Argentina \\ ${ }^{2}$ Instituto de Geología y Recursos Naturales, Centro de Investigación e Innovación Tecnológica, Universidad Nacional de La Rioja \\ (INGeReN-CENIIT-UNLaR), Avenida Gobernador Vernet y Apostol Felipe, 5300, La Rioja, Argentina \\ ${ }^{3}$ Departamento de Petrología y Geoquímica, Universidad Complutense, Instituto de Geociencias (CSIC-UCM), 28040 Madrid, Spain \\ ${ }^{4}$ Visiting Research Associate, British Geological Survey, Keyworth, Nottingham NG12 5GG, UK \\ ${ }^{5}$ Centro de Investigaciones Geológicas (CIG), Consejo Nacional de Investigaciones Científicas y Técnicas (CONICET)- \\ Universidad Nacional de La Plata (UNLP), Calle 1 No. 644, 1900, La Plata, Argentina \\ ${ }^{6}$ Centro de Investigaciones en Ciencias de la Tierra (CICTERRA). Consejo Nacional de Investigaciones Científicas y Técnicas \\ (CONICET)-Universidad Nacional de Córdoba (UNC). Avenida Vélez Sarsfield 1611. Ciudad Universitaria X5016GCA, Argentina \\ ${ }^{7}$ Laboratorio de Isótopos Estables, Edificio Multiusos I+D+i, Universidad de Salamanca, E-37007 Salamanca, Spain \\ ${ }^{8}$ Department of Earth Sciences, University of Southern California, Los Angeles, California 90089-0740, USA
}

\section{ABSTRACT}

We studied the petrogenesis of mafic igneous rocks in the Famatinian arc in the western Sierra Famatina (NW Argentina), an Early Ordovician middle-crustal section in the proto-Andean margin of Gondwana. Mafic rock types consist of amphibolite, metagabbro, and gabbro, as well as pod- and dike-like bodies of gabbro to diorite composition. Field relations together with geochemical and isotopic data for the mafic rocks of the western Sierra de Famatina (at $29^{\circ} \mathrm{S}$ ) define two contrasting suites, which can be correlated with similar assemblages noted in other parts of the orogen. Amphibolite, metagabbro, and gabbro bodies are mostly the oldest intrusive rocks (older than $480 \mathrm{Ma}$ ), with the host tonalite and post-tonalite mafic dikes being slightly younger. The older mafic suite is tholeiitic to calc-alkaline and isotopically evolved, except for most of the amphibolite samples. The younger suite is calc-alkaline, typically displaying subduction-related geochemical signatures, and it is isotopically more juvenile. Whole-rock chemical composition and isotopic analyses are compatible with a progressive mixing of different isotopic reservoirs. Pyroxenite ( \pm garnet) was likely the dominant source of the older gabbroic magmas, whereas peridotite dominated

’palasino@crilar-conicet.gob.ar in the source of the younger suite, implying that the mafic magma experienced a progressive shift toward more juvenile compositions though time (over 20 m.y.). Pyroxenitederived melts could have been generated by lithospheric foundering followed by upwelling of primitive melts by adiabatic decompression of mantle wedge peridotite.

\section{INTRODUCTION}

Continental crust is the most prominent manifestation of silicate differentiation on Earth. Unlike the formation of oceanic crust by decompression melting of the upper mantle at mid-ocean ridges, the formation of continental crust at convergent margins of Andean/Cordilleran type remains a subject of debate. Although liquids generated by melting of the mantle require diversification processes such as differentiation and contamination in the crust to produce intermediate and felsic magmas, an understanding of the large-scale interaction between deep lithosphere and the underlying asthenospheric mantle is critical (e.g., Lee, 2014, and references therein). The removal of the deep lithosphere may be relevant to the initiation of voluminous magmatism in the overriding plate (e.g., Kay et al., 1994). The cold and negatively buoyant lithospheric mantle, composed of garnet-pyroxenite and melt-depleted peridotite (commonly metasomatized), would be unstable and could potentially founder or be subducted into the asthenospheric convecting mantle. In recent years, foundering processes have been invoked on the basis of regional geochemical shifts of magma compositions that indicate a more primitive asthenospheric source over time scales of tens of millions of years (e.g., Kay and Kay, 1993; Manthei et al., 2010; GutierrezAlonso et al., 2011; Putirka and Platt, 2012; Ducea et al., 2013).

The Early to Middle Ordovician Famatinian arc along the southwestern Gondwana margin between present-day Patagonia and Venezuela produced abundant magmatism in the Sierras Pampeanas in central and northwestern Argentina (e.g., Pankhurst et al., 1998). This arc consists of relatively abundant mafic and intermediate igneous rocks (Pankhurst et al., 1998, 2000; Dahlquist et al., 2007, 2008, 2013; Otamendi et al., 2009, 2012) and has been related to subduction along the western margin of Gondwana between ca. $486 \mathrm{Ma}$ and $463 \mathrm{Ma}$ (e.g., Pankhurst et al., 2000; Dahlquist et al., 2008; Chernicoff et al., 2010; Ducea et al., 2010; Hongn et al., 2014). The granitoids display a wide range of isotopic signatures $\left(\varepsilon_{\mathrm{Nd}}[t]+4.8\right.$ to -6$)$, indicating that this arc magmatism reworked old lithospheric sources (Pankhurst et al., 2000; Dahlquist et al., 2008, 2013; Rapela et al., 2008; Casquet et al., 2012a; Ducea et al., 2015). Our understanding of the petrogenesis of Famatinian granitoids has improved over the last $15 \mathrm{yr}$ (e.g., Bahlburg and Hervé, 1997; Pankhurst et al., 1998, 2000; Dahlquist et al., 2008, 2013; Otamendi et al., 

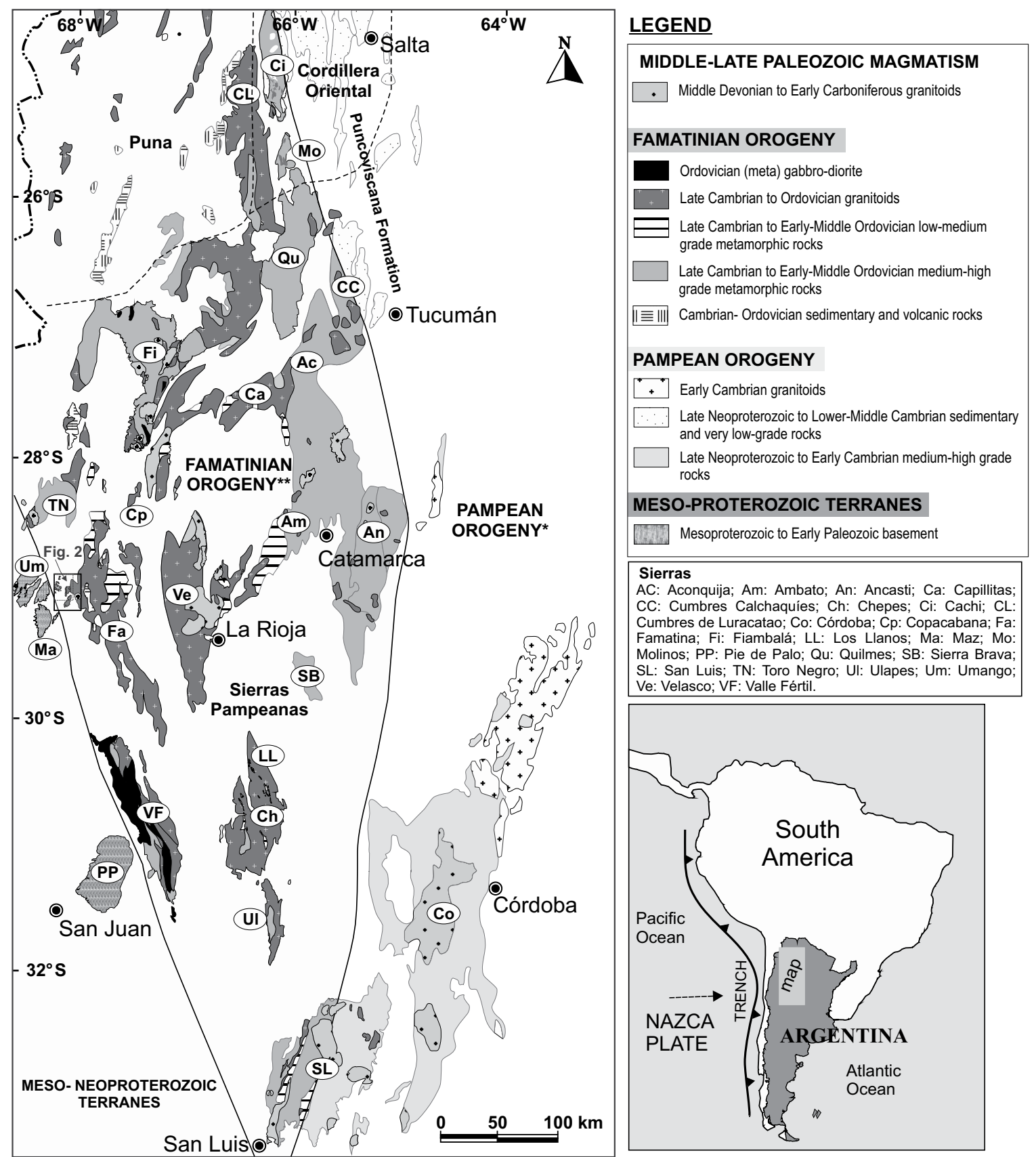

Figure 1. Generalized sketch map of the Sierras Pampeanas and southern Puna showing the main lithologies and distribution of the Pampean and Famatinian orogenic belts. The area of study is indicated by the box. *In part reworked by the Famatinian orogeny. ** Internal zone of the orogen.

2009, 2012; Ducea et al., 2010, 2015; Alasino et al., 2014; and references therein), but many key aspects of the initiation and evolution of this arc are not well understood. In this contribution, we present an updated and expanded description of field relations, petrography, and composition of mafic Ordovician rocks in the western flank of the Sierra de Famatina in the area around $29^{\circ} \mathrm{S}$, one of the ranges where Famatinian magmatic rocks crop out extensively. These new data, along with a review of available information from the Sierra de Valle Fértil and Sierra de Los Llanos (see Fig. 1) and their comparison with some localities from the Puna region (see Table DR $1^{1}$ ), suggest a progressive geochemical shift with time of the Famatinian mafic magmatism toward more asthenospheric sources. This evidence is used to infer a large-scale mantle evolution under the Famatinian magmatic arc in northwestern Argentina.

${ }^{1}$ GSA Data Repository item 2016085, DR1: Whole-rock geochemistry and Sr-Nd isotope systematics of selected rock samples; DR2: Representative microprobe analyses of minerals in mafic rocks of the western Sierra de Famatina, is available at http://www.geosociety.org/pubs/ft2016.htm or by request to editing@geosociety.org. 


\section{GEOLOGICAL SETTING}

\subsection{Famatinian Arc}

Along the $27^{\circ} \mathrm{S}-33^{\circ} \mathrm{S}$ flat-slab segment of the Nazca plate in the southern Andes (Fig. 1), present-day landforms result from basement uplift along Miocene to Holocene reverse faults located up to $900 \mathrm{~km}$ away from the trench (e.g., Jordan and Allmendinger, 1986). These basement exposures constitute the Sierras Pampeanas, which extend from the 2.0-2.2 Ga (Paleoproterozoic) Río de la Plata craton in the east to the modern Andes in the west. The Sierras Pampeanas consist of igneous and metamorphic rocks of Mesoproterozoic to Ordovician age that record a complex paleogeographic and tectonic history extending in time from the Grenvillian orogeny to the early Paleozoic accretion to Gondwana (e.g., Casquet et al., 2012b; Rapela et al., 2015). Further, the region preserves a well-exposed remnant of the proto-Andean active margin of Gondwana represented by the Famatinian magmatic arc, with contemporaneous deformation and hightemperature-medium-pressure metamorphism, i.e., the Famatinian orogeny. U-Pb zircon ages constrain Famatinian magmatism to between $486 \mathrm{Ma}$ and $463 \mathrm{Ma}$. The belt displays wellexposed sections across the transition from lower- to midcrustal levels of the arc (e.g.,
Pankhurst et al., 2000; Dahlquist et al., 2005a, 2007; Grosse et al., 2011; Otamendi et al., 2012). A continuous section, $\sim 15 \mathrm{~km}$ long, of pre-Triassic tilted arc crust in the Sierra de Valle Fértil (Fig. 1) shows inferred paleodepths of 15-30 km (Otamendi et al., 2012). Here, granodiorite and tonalite dominate the middle crust down to $\sim 20 \mathrm{~km}$ depth, tonalite and diorite from 20 to $25 \mathrm{~km}$ depth, and gabbro from 25 to $30 \mathrm{~km}$ depth (e.g., Tibaldi et al., 2013). The Sierra de Valle Fértil section of the arc records protracted intrusion of mafic magmas throughout the life of the magmatic arc (Otamendi et al. 2012). Field geological evidence further shows that arc activity began with mafic magmatism (gabbro) and that tonalite-granodiorite magmatism developed somewhat later. Host rocks are medium-pressure, upper-amphibolite- to granulite-facies metasedimentary rocks $(6 \pm 1$ kbar, $800 \pm 40{ }^{\circ} \mathrm{C}$; Otamendi et al., 2008). To the west of the Sierra de Valle Fértil, high-pressure, upper-amphibolite-facies paragneiss (12 \pm $1 \mathrm{kbar}, 780 \pm 45^{\circ} \mathrm{C}$; Casquet et al., 2012a) was recognized at the small outcrop of Las Chacras (Fig. 1). Although separated from the rest of the Sierra de Valle Fértil by shear zones and faults, the Las Chacras outcrop was interpreted as a subducted and forearc basin underplated to the arc (Casquet et al., 2012a).

Evidence for large-scale interaction between partially molten country rocks and metalumi- nous tonalitic magmas at midcrustal level is preserved in the western flank of Sierra de Famatina (Saavedra et al., 1992; Alasino et al., 2014), where the Cerro Toro igneous complex (Toselli et al., 1988; Saavedra et al., 1992) consists of a succession of steeply dipping N-S-trending sheets of tonalite and less abundant granodiorite. Host rocks are high-grade metasedimentary rocks $\left(5 \pm 1 \mathrm{kbar}, 750 \pm 40{ }^{\circ} \mathrm{C}\right.$; Alasino et al., 2014). The metamorphic grade increases eastward from amphibolite to granulite facies. Pelitic migmatite together with amphibolite and metagabbro occur as screens and stoped blocks in the igneous complex, and these rocks together constitute the medium-pressure-hightemperature Cerro Toro regional thermal aureole (Fig. 2). Emplacement of metaluminous magma and regional metamorphism were largely coeval (e.g., Alasino et al., 2014). U-Pb sensitive highresolution ion microprobe (SHRIMP) zircon dating of a hybrid rock (sample FAM7086) from the intermediate zone yielded an age of $481 \pm$ 4 Ma with highly negative $\varepsilon_{\mathrm{Hf}}(t)$ values in zircon (average $=-14.7$ ), typical of a supracrustal component (Dahlquist et al., 2008, 2013). We consider this to be the age of formation of the Cerro Toro aureole.

In places where shallower levels of the magmatic arc are preserved, such as in the Sierra de Los Llanos, the granitoids dominantly consist of granodiorite, with lesser biotite monzo-

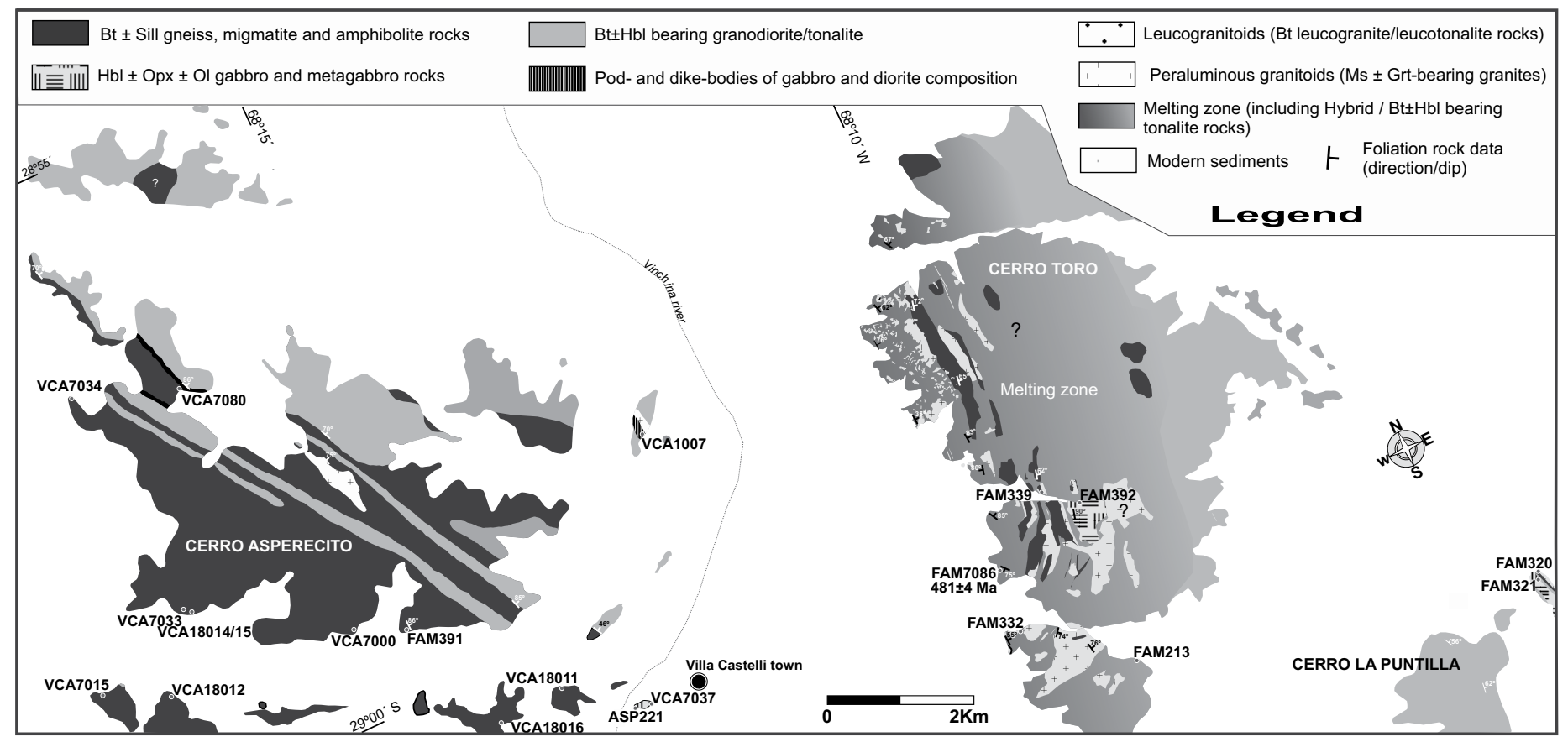

Figure 2. Simplified geological map of the Cerro Toro thermal aureole in the western Sierra de Famatina and localization of the main sampling sites modified from Alasino et al. (2014). Mineral abbreviations: Bt—biotite; Sill—sillimanite; Hbl—hornblende; Opx—orthopyroxene; Ol-olivine; Ms—muscovite; Grt-garnet. 
granite, and highly peraluminous varieties including two-mica cordierite monzogranite (Pankhurst et al., 1998). Small, discontinuous outcrops of metamorphic rocks occur as stoped blocks and roof pendants in the granodiorite. The metasedimentary sequence predominantly consists of Cambrian metapelite, alternating with beds of metamorphosed siltstone and sandstone (e.g., Pankhurst et al., 1998; Collo et al., 2009; Cristofolini et al., 2012; Verdecchia et al., 2014). The granitoids were emplaced at low pressure (2.7-3.6 kbar) and high temperature (780-850 ${ }^{\circ} \mathrm{C}$ ); metamorphism was associated with emplacement of the metaluminous granitoids (Dahlquist et al., 2005a). We focus hereafter on the western Sierra de Famatina outcrops of Famatinian mafic rocks.

\subsection{Mafic Rocks of Western Sierra de Famatina}

Mafic rock types were distinguished on the basis of the field relations, texture, and mineralogy (Fig. 2). They are grouped as:

(1) Amphibolite is part of the high-grade metamorphic series exposed mainly at Cerro Asperecito (part of the external zone of the Cerro Toro aureole) as lens-shaped or tabular bodies, meters to tens of meters thick (former sills), and concordant with the regional steeply dipping NNW-SSE metamorphic foliation. They also occur in the intermediate zone of the aureole as stoped blocks in tonalite and hybrid or leucogranitoid rocks (Fig. 3A). Contacts with the host are mostly sharp. Amphibolite consists mostly of amphibole and plagioclase with a pronounced planar structure.

(2) Metagabbro and gabbro form numerous sills and small bodies that intruded the highgrade metasedimentary rocks. These mafic rocks occur as rafts or stoped blocks in the intermediate and internal zones (Fig. 3A). Contact relationships vary along the regional steeply dipping NNW-SSE foliation; they can be sharp, or complex with multiple magma injections, stoping and mingling with hybrid rocks of the Cerro Toro aureole (Fig. 3B). Petrographically, the metagabbro may have olivine and pyroxene crystals and shows evidence of metamorphic changes at near-liquidus and lower temperatures (see section 4.2). Unlike most amphibolite rocks, metagabbro lacks a planar structure. Gab-
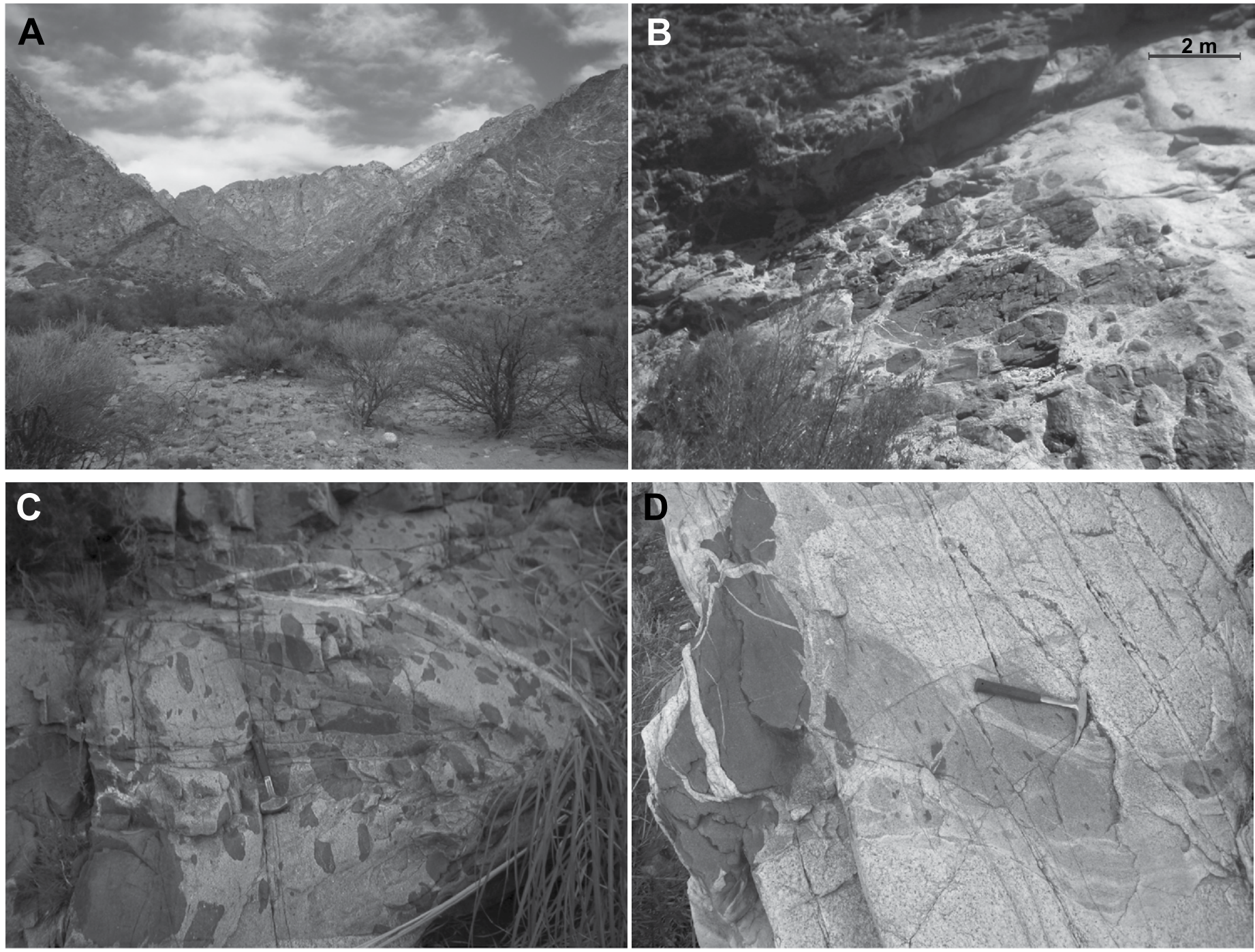

Figure 3. (A) Mafic rafts and blocks of amphibolite and metagabbro surrounded by granitoid sheeted bodies. (B-C) Mingling relationships between granitoid and contemporaneous mafic dikes (in places leading to stoped blocks) in Sierra de Famatina. (D) Dismembered mafic intrusions in tonalite interpreted to have been magma mush, forming enclaves with mafic trajectories (or "wakes"). Photograph was taken on a fallen block (not in situ). 
bro also crops out as a small body $\left(\sim 300 \mathrm{~m}^{2}\right)$ to the southeast of Cerro Asperecito (Fig. 2). The rocks vary gradually from inequigranular, coarse- to medium-grained, to equigranular and fine-grained rocks. They are green-black in color and rich in amphibole.

(3) Pod- and dike-like bodies of gabbro and diorite composition commonly intrude tonalite. Their contacts are lobate where the tonalitic melt back-intruded the mafic bodies, and in places display hybridization. In other cases, exceptionally well-developed mechanical interactions, such as sinking structures, were observed (Fig. 3C). Here, mafic intrusions into the tonalite magma mush were dismembered, forming enclaves. They are characterized by dropshaped geometry indicating vertical movement, in some places showing trails (or "wakes") of mafic minerals (Fig. 3D).

\section{SAMPLING AND ANALYTICAL METHODS}

More than 30 samples were collected for petrography, of which 11 (six amphibolite samples; four metagabbro-gabbro samples; one dioritic dike) were selected for whole-rock majorand trace-element analyses using inductively coupled plasma-optical emission spectrometry (ICP-OES) and inductively coupled plasmamass spectrometry (ICP-MS) at ACTLABS, Canada (Table 1). Samples were first fused with lithium metaborate/tetraborate and then dissolved in nitric acid. Major elements, Be, $\mathrm{Sc}, \mathrm{V}, \mathrm{Sr}, \mathrm{Ba}$, and $\mathrm{Zr}$ were determined by ICPOES; all other trace elements were determined by ICP-MS. Precision and accuracy for major elements were generally better than $2 \%$ (relative); for trace elements, they were generally better than $\pm 6 \%$ when signals were 10 times above background. Additionally, two representative igneous samples (one metagabbro and one amphibolite) were analyzed by GeoAnalytical Laboratory, Washington State University, using a ThermoARL sequential X-ray fluorescence spectrometer, following the procedure described by Johnson et al. (1999). Trace element compositions were determined using an Agilent 7700 ICP-MS, following the procedure described in http://cahnrs.wsu.edu/soe/facilities/geolab /technotes/icp-ms_method.

Mineral compositions were measured using a JEOL JXA 8230 microprobe at LAMARXNational University of Córdoba (WDS mode, $15 \mathrm{kV}, 20 \mathrm{nA}, 10 \mathrm{nA}$ for plagioclase) on carboncoated polished mounts. The beam diameter was $3 \mu \mathrm{m}$ ( $8 \mu \mathrm{m}$ for plagioclase), with counting time of $10 \mathrm{~s}$ on the peak and $5 \mathrm{~s}$ at each

TABLE 1. MAJOR- AND TRACE-ELEMENT COMPOSITIONS OF MAFIC SAMPLES FROM WESTERN SIERRA DE FAMATINA

\begin{tabular}{|c|c|c|c|c|c|c|c|c|c|c|c|c|}
\hline \multirow{3}{*}{$\begin{array}{l}\text { Sample } \\
\text { Number: }\end{array}$} & \multicolumn{7}{|c|}{ Amphibolite } & \multicolumn{3}{|c|}{ Metagabbro-gabbro } & \multicolumn{2}{|c|}{ Pod- and dike-like bodies } \\
\hline & FAM & VCA & VCA & VCA & VCA & VCA & FAM & FAM & VCA $7037^{\S}$ & ASP & VCA & FAM \\
\hline & $320^{*}$ & 7000 & 7015 & 7033 & 7034 & 7080 & $321^{\dagger}$ & $392^{* \dagger}$ & & $221^{\S}$ & $1007^{\S}$ & $176^{\#}$ \\
\hline \multicolumn{13}{|c|}{ Major oxides (wt\%) } \\
\hline $\mathrm{SiO}_{2}$ & 54.32 & 52.61 & 50.31 & 53.14 & 51.13 & 51.71 & 49.67 & 45.83 & 46.88 & 45.77 & 46.50 & 53.88 \\
\hline $\mathrm{TiO}_{2}$ & 0.85 & 0.67 & 0.43 & 0.70 & 0.77 & 0.64 & 0.26 & 0.19 & 0.56 & 0.50 & 1.10 & 0.84 \\
\hline $\mathrm{Al}_{2} \mathrm{O}_{3}$ & 17.5 & 14.26 & 15.51 & 13.9 & 15.8 & 15.35 & 19.03 & 20.97 & 17.08 & 16.96 & 18.07 & 15.85 \\
\hline $\mathrm{FeO}^{\mathrm{t}}$ & 8.75 & 8.02 & 8.26 & 8.28 & 8.74 & 7.5 & 6.71 & 8.27 & 10.18 & 12.54 & 12.73 & 8.9 \\
\hline $\mathrm{MnO}$ & 0.23 & 0.16 & 0.13 & 0.16 & 0.16 & 0.14 & 0.17 & 0.13 & 0.11 & 0.23 & 0.23 & 0.16 \\
\hline $\mathrm{MgO}$ & 4.75 & 8.99 & 10.14 & 8.58 & 7.4 & 8.26 & 8.96 & 8.93 & 9.06 & 10.04 & 5.86 & 5.28 \\
\hline $\mathrm{CaO}$ & 8.35 & 11.67 & 12.77 & 11.13 & 11.31 & 12.33 & 11.84 & 12.60 & 12.22 & 10.71 & 10.66 & 8.82 \\
\hline $\mathrm{Na}_{2} \mathrm{O}$ & 3.64 & 1.21 & 1.63 & 1.79 & 1.83 & 1.34 & 1.26 & 1.02 & 1.27 & 0.84 & 1.82 & 2.7 \\
\hline $\mathrm{K}_{2} \mathrm{O}$ & 1.45 & 0.43 & 0.49 & 0.71 & 0.62 & 0.25 & 2.07 & 0.4 & 0.30 & 0.17 & 0.89 & 1.25 \\
\hline $\mathrm{P}_{2} \mathrm{O}_{5}$ & 0.18 & 0.08 & 0.05 & 0.08 & 0.08 & 0.07 & 0.02 & 0.04 & 0.05 & 0.02 & 0.19 & 0.14 \\
\hline Total & 100.02 & 98.10 & 99.72 & 98.47 & 97.84 & 97.59 & 99.99 & 98.38 & 97.71 & 97.78 & 98.05 & 97.82 \\
\hline \multicolumn{13}{|l|}{ ppm } \\
\hline Cs & 2.28 & 0.5 & 0.8 & 1.0 & 0.5 & 0.3 & 7.19 & 1.1 & 0.7 & 0.6 & 1.5 & 2.3 \\
\hline $\mathrm{Rb}$ & 63.3 & 7.4 & 16.5 & 15.4 & 13.6 & 4 & 123 & 10 & 10 & 5 & 30 & 48 \\
\hline $\mathrm{Sr}$ & 179 & 118 & 94.1 & 129 & 176 & 96 & 162 & 166 & 140 & 140 & 235 & 202 \\
\hline $\mathrm{Ba}$ & 135 & 57.5 & 54.1 & 137 & 55.0 & 48 & 169 & 58 & 41 & 29 & 141 & 329 \\
\hline $\mathrm{La}$ & 16.9 & 7.83 & 3.69 & 8.48 & 8.15 & 6.45 & 2.17 & 2.51 & 4.13 & 1.75 & 15.8 & 14.4 \\
\hline $\mathrm{Ce}$ & 36.1 & 19.7 & 9.15 & 20.7 & 20.2 & 15.9 & 4.97 & 7 & 11.5 & 3.91 & 44.6 & 32.9 \\
\hline $\mathrm{Pr}$ & 4.83 & 2.1 & 1.01 & 2.24 & 2.24 & 1.73 & 0.68 & N.D. ** & 1.3 & 0.49 & 5.97 & 3.78 \\
\hline $\mathrm{Nd}$ & 20.2 & 9.09 & 4.61 & 9.77 & 10.1 & 7.74 & 2.96 & 4 & 6.15 & 2.27 & 26.9 & 14.9 \\
\hline $\mathrm{Sm}$ & 4.91 & 2.31 & 1.28 & 2.52 & 2.6 & 2.03 & 0.92 & 0.78 & 1.62 & 0.6 & 6.19 & 3.62 \\
\hline $\mathrm{Eu}$ & 1.54 & 0.72 & 0.44 & 0.73 & 0.8 & 0.67 & 0.35 & 0.29 & 0.53 & 0.28 & 1.42 & 1.05 \\
\hline Gd & 4.95 & 2.59 & 1.51 & 2.68 & 3.03 & 2.52 & 1.09 & N.D. & 1.78 & 0.65 & 5.35 & 3.64 \\
\hline $\mathrm{Tb}$ & 0.84 & 0.43 & 0.28 & 0.49 & 0.53 & 0.43 & 0.2 & $<0.1$ & 0.3 & 0.12 & 0.96 & 0.62 \\
\hline Dy & 5.3 & 2.87 & 1.86 & 3.16 & 3.47 & 2.81 & 1.37 & N.D. & 1.94 & 0.79 & 5.47 & 3.42 \\
\hline $\mathrm{Ho}$ & 1.1 & 0.63 & 0.4 & 0.67 & 0.74 & 0.59 & 0.3 & N.D. & 0.4 & 0.17 & 1.09 & 0.7 \\
\hline $\mathrm{Er}$ & 3.1 & 1.84 & 1.19 & 1.98 & 2.21 & 1.83 & 0.88 & N.D. & 1.18 & 0.5 & 3.17 & 2.16 \\
\hline $\mathrm{Tm}$ & 0.45 & 0.28 & 0.19 & 0.31 & 0.34 & 0.28 & 0.14 & N.D. & 0.17 & 0.08 & 0.46 & 0.33 \\
\hline $\mathrm{Yb}$ & 2.85 & 1.72 & 1.15 & 1.89 & 2.09 & 1.7 & 0.94 & 0.89 & 1.06 & 0.52 & 2.96 & 2.06 \\
\hline $\mathrm{Lu}$ & 0.47 & 0.28 & 0.18 & 0.29 & 0.32 & 0.27 & 0.16 & 0.13 & 0.15 & 0.09 & 0.44 & 0.28 \\
\hline$U$ & 1.55 & 0.52 & 0.25 & 0.53 & 0.69 & 0.42 & 0.39 & 0.3 & 0.21 & 0.06 & 0.17 & 0.89 \\
\hline Th & 3.56 & 2.04 & 1.05 & 2.11 & 2.35 & 1.68 & 0.48 & 0.6 & 0.89 & 0.33 & 0.45 & 5.87 \\
\hline$Y$ & 28.5 & 18 & 11.4 & 19.1 & 21.3 & 16.7 & 8.03 & 7 & 10.8 & 4.1 & 27 & 18.7 \\
\hline $\mathrm{Nb}$ & 4.96 & 3.1 & 2 & 3.5 & 3.8 & 3.3 & 1.84 & N.D. & 2.9 & 0.6 & 8 & 4.7 \\
\hline $\mathrm{Zr}$ & 93.7 & 71.8 & 36.2 & 77.1 & 77 & 57 & 9.41 & 21 & 25 & 7 & 101 & 78 \\
\hline $\mathrm{Hf}$ & 2.76 & 1.8 & 0.98 & 1.94 & 1.96 & 1.5 & 0.34 & 0.5 & 0.8 & 0.3 & 2.9 & 2.2 \\
\hline $\mathrm{Ta}$ & 0.45 & 0.16 & 0.1 & 0.2 & 0.22 & 0.14 & 0.24 & $<0.3$ & 0.08 & 0.03 & 1.15 & 0.19 \\
\hline Co & N.D. & 37.1 & 29.9 & 37.1 & 38.5 & 32 & N.D. & 50.1 & 45 & 45 & 53 & 29 \\
\hline $\mathrm{Cr}$ & 68 & 388 & 980 & 337 & 77.5 & 591 & 311 & 261 & 168 & 180 & 59 & 82 \\
\hline $\mathrm{Pb}$ & 10 & N.D. & N.D. & N.D. & N.D. & N.D. & 7 & 3 & 3 & 13 & 6 & 10 \\
\hline
\end{tabular}

Note: Total iron expressed as FeOtotal. Sample VCA1007 is from Pankhurst et al. (2000)

*Samples analyzed by GeoAnalytical Laboratory, Washington State University.

†Metagabbro.

§abbro.

\#Diorite.

${ }^{\star *}$ N.D.- not determined. 
Geological Society of America Bulletin, published online on 20 April 2016 as doi:10.1130/B31417.1

Alasino et al.

TABLE 2. Rb-Sr AND Sm-Nd DATA FOR MAFIC SAMPLES FROM THE WESTERN SIERRA DE FAMATINA

\begin{tabular}{|c|c|c|c|c|c|c|c|c|c|c|c|c|}
\hline Sample number & $\begin{array}{c}\mathrm{Rb} \\
(\mathrm{ppm})\end{array}$ & $\begin{array}{c}\mathrm{Sr} \\
(\mathrm{ppm})\end{array}$ & ${ }^{87} \mathrm{Rb} /{ }^{86} \mathrm{Sr}$ & ${ }^{87} \mathrm{Sr} /{ }^{86} \mathrm{Sr}$ & ${ }^{87} \mathrm{Sr} /{ }^{86} \mathrm{Sr}_{\mathrm{t}}^{*}$ & $\begin{array}{c}\mathrm{Sr} \\
(\mathrm{ppm})\end{array}$ & $\begin{array}{c}\mathrm{Nd} \\
(\mathrm{ppm})\end{array}$ & ${ }^{147} \mathrm{Sm} /{ }^{144} \mathrm{Nd}$ & ${ }^{143} \mathrm{Sm} /{ }^{144} \mathrm{Nd}$ & ${ }^{147} \mathrm{Sm} /{ }^{144} \mathrm{Nd}_{\mathrm{t}}$ & $\varepsilon_{N d}(t)^{\dagger}$ & $\mathrm{T}_{\mathrm{DM}} \S$ \\
\hline \multicolumn{13}{|l|}{ Amphibolite } \\
\hline VCA-7000 & 7 & 119 & 0.1804 & 0.708359 & 0.707125 & 2.31 & 9.09 & 0.1536 & 0.512441 & 0.511958 & -1.2 & 1.30 \\
\hline VCA-7015 & 17 & 94 & 0.5092 & 0.710033 & 0.706551 & 1.28 & 4.61 & 0.1679 & 0.512500 & 0.511972 & -0.9 & 1.28 \\
\hline VCA-7033 & 15 & 129 & 0.3459 & 0.709650 & 0.707284 & 2.52 & 9.77 & 0.1559 & 0.512427 & 0.511937 & -1.6 & 1.33 \\
\hline VCA-7034 & 14 & 177 & 0.2244 & 0.713806 & 0.712271 & 2.60 & 10.1 & 0.1556 & 0.512500 & 0.512011 & -0.2 & 1.22 \\
\hline VCA-7080 & 4 & 96 & 0.1205 & 0.707108 & 0.706284 & 2.03 & 7.74 & 0.1586 & 0.512534 & 0.512035 & +0.3 & 1.18 \\
\hline VCA-18011 & 6.3 & 126 & 0.1445 & 0.707430 & 0.706441 & 1.17 & 4.75 & 0.1493 & 0.512504 & 0.512035 & +0.3 & 1.18 \\
\hline VCA-18012 & 5.4 & 189 & 0.0827 & 0.710211 & 0.709645 & & & & & & & \\
\hline VCA-18014 & 9.4 & 134 & 0.2025 & 0.708042 & 0.706657 & 1.26 & 5.21 & 0.1463 & 0.512226 & 0.511766 & -5.0 & 1.59 \\
\hline VCA-18015 & 15 & 132 & 0.3327 & 0.709323 & 0.707047 & 1.67 & 6.89 & 0.1465 & 0.512438 & 0.511977 & -0.8 & 1.27 \\
\hline VCA-18016 & 9.9 & 100 & 0.2853 & 0.708166 & 0.706215 & 1.26 & 4.85 & 0.1569 & 0.512409 & 0.511926 & -2.1 & 1.37 \\
\hline \multicolumn{13}{|l|}{ Metagabbro } \\
\hline FAM-392 & 10 & 166 & 0.1743 & 0.709351 & 0.708157 & 0.78 & 4 & 0.1179 & 0.512276 & 0.511905 & -2.2 & 1.39 \\
\hline \multicolumn{13}{|l|}{ Pod-like body } \\
\hline VCA-1007 & 31 & 242 & 0.3694 & 0.709240 & 0.706777 & 5.46 & 23.5 & 0.1403 & 0.512276 & 0.511846 & -3.7 & 1.49 \\
\hline \multicolumn{13}{|c|}{$\begin{array}{l}\text { Note: The decay constants used in the calculations are the values } \lambda^{87} \mathrm{Rb}=1.42 \times 10^{-11} \text { and } \lambda^{147} \mathrm{Sm}=6.54 \times 10^{-12} \mathrm{yr}{ }^{-1} \text { recommended by the IUGS Subcommission for } \\
\text { Geochronology (Steiger and Jäger, } 1977) \text {. } \\
{ }^{*} t \text {-time used for the calculation of the isotopic initial ratios. For metagabbro and amphibolite, } t=480 \mathrm{Ma} \text {, and for gabbro, } t=475 \mathrm{Ma} \text {. } \\
{ }^{\dagger} \text { Epsilon-Nd values were calculated relative to a present-day chondrite: }\left({ }^{143} \mathrm{Nd} /{ }^{144} \mathrm{Nd}\right)^{\text {today }} \mathrm{CHUR}=0.512638 ;\left({ }^{143} \mathrm{Sm} /{ }^{144} \mathrm{Nd}\right)^{\text {today }} \mathrm{CHUR}=0.1967 \text {, where } \mathrm{CHUR} \text { is chondritic } \\
\text { uniform reservoir. } \\
{ }^{\S} \mathrm{T}_{\mathrm{DM}} \text { is depleted mantle model age with average crustal } \mathrm{Sm} / \mathrm{Nd} \text { prior to emplacement at } 470 \mathrm{Ma} \text {, following DePaolo et al. (1991). }\end{array}$} \\
\hline
\end{tabular}

background position. Minerals and synthetic compounds were used as standards. Results are shown in Table DR2 (see footnote 1).

$\mathrm{Sr}$ and $\mathrm{Nd}$ isotopic analyses of 12 samples, including 10 amphibolite samples, one metagabbro sample, and one gabbro sample, were carried out at the Geochronology and Isotope Geochemistry Center, Complutense University (Madrid, Spain), using an automated multicollector VG® SECTOR 54 mass spectrometer (Table 2). Errors are quoted throughout as two standard deviations from measured or calculated values. Analytical uncertainties were estimated to be $0.006 \%$ for ${ }^{143} \mathrm{Nd} /{ }^{144} \mathrm{Nd}$ and $0.1 \%$ ${ }^{147} \mathrm{Sm} /{ }^{144} \mathrm{Nd}$, with the latter parameter determined by isotope dilution. Fifty-six analyses of the La Jolla Nd standard over 1 yr gave a mean ${ }^{143} \mathrm{Nd} /{ }^{144} \mathrm{Nd}$ ratio of $0.511846 \pm 0.00003$.

Oxygen isotope analyses of three rock types (one olivine-pyroxene metagabbro, one mafic dike, and a small hornblende-gabbro body) were determined at the Servicio General de Análisis de Isótopos Estables, University of Salamanca, Spain, on whole-rock powders by laser fluorination (Clayton and Mayeda, 1963), employing a Synrad $25 \mathrm{~W} \mathrm{CO}_{2}$ laser (Sharp, 1990) and $\mathrm{ClF}_{3}$ as reagent (e.g., Borthwick and Harmon, 1982). Two migmatite samples of the Cerro Toro aureole, one tonalite sample, and one hybrid rock sample were also analyzed for comparison (Table 3). Isotope ratios were measured on a VG-Isotech SIRA-II dual-inlet mass spectrometer. Both internal and international reference standards (NBS-28, NBS-30) were run to check accuracy and precision. Results are reported in $\delta^{18} \mathrm{O}$ notation relative to the Vienna standard mean ocean water (V-SMOW) standard, using a $\delta^{18} \mathrm{O}$ value of $9.6 \%$ for NBS-28 (quartz) for the mass spectrometer calibration. Long-term reproducibility for repeated determination of reference samples was better than $\pm 0.2 \%$ o $(1 \sigma)$.

\section{PETROGRAPHY AND MINERAL CHEMISTRY}

\subsection{Amphibolite}

Two amphibolite types are distinguished based on texture: (1) medium-grained granoblastic formed by hornblende (55 modal \%), plagioclase $(40 \%)$, and quartz $(4 \%)$, with titanite, apatite, and opaque phases as accessory minerals, and (2) fine-grained nematoblastic consisting of hornblende (71\%), plagioclase (23\%), quartz (5\%), and opaque minerals (less than $1 \%$ ). Microprobe analyses of a nematoblastic amphibolite show that the amphibole belongs to the calcic group and can be classified as magnesiohornblende according to Hawthorne et al. (2012). The ratio $\mathrm{Mg} /\left(\mathrm{Mg}+\mathrm{Fe}^{2+}\right)$ is between 0.58 and 0.63 . Plagioclase crystals range from $\mathrm{An}_{47}$ to $\mathrm{An}_{64}$.

\subsection{Metagabbro and Gabbro}

Metagabbro, composed of plagioclase (46 modal \%), amphibole (37\%), and orthopyroxene $(14 \%)$ as essential minerals, is medium grained $(3-6 \mathrm{~mm})$ with relics of primary (igneous) texture, consisting typically of large cumulate crystals of plagioclase and clinopyroxene, with smaller olivine crystals overprinted by late- to postmagmatic changes (metamorphism). The former two minerals were transformed into a recovered polygo- nal aggregate. Olivine in turn shows a typical multilayer coronitic texture along the contact. Olivine relics are enveloped by orthopyroxene, which in turn is separated from plagioclase by a metamorphic assemblage consisting of clinoamphibole showing symplectic intergrowth with a spinel-hercynite solid solution, and biotite. Amphibole occurs as large single crystals or transformed into polycrystalline disoriented aggregates. Olivine crystals are unzoned (Fo 71) and have $\mathrm{Cr}$ and $\mathrm{Ca}$ below detection limits. Nickel is very low (up to $0.08 \mathrm{wt} \% \mathrm{NiO}$ ). Plagioclase crystals almost reach the $\mathrm{Ca}$ end member (An 98-99). Cores are partially altered to clay minerals and finegrained epidote-clinozoisite; plagioclase also hosts tiny amphibole and spinel solid solution (s.s.) grains. Orthopyroxene $\left(\mathrm{En}_{72.9-74.9} \mathrm{Fs}_{24.0-25.8}\right.$ $\left.\mathrm{Wo}_{0.2-0.6} \mathrm{Ac}_{0.5-0.8}\right)$ contains very few inclusions of ilmenite and magnetite. Amphibole can be classified as magnesiohornblende according to Hawthorne et al. (2012); the $\mathrm{Mg} /\left(\mathrm{Mg}+\mathrm{Fe}^{2+}\right)$ ratio varies between 0.58 and 0.83 . Magnetite and ilmenite occur as euhedral to subhedral crystals, some of them skeletal, up to $100 \mu \mathrm{m}$

TABLE 3. OXYGEN ISOTOPE DATA FOR SAMPLES FROM THE WESTERN SIERRA DE FAMATINA

\begin{tabular}{lcc}
\hline \hline Sample number & Rock type & $\begin{array}{c}\delta^{18} \mathrm{O}_{\text {SMOW }} \\
(\% \circ)\end{array}$ \\
\hline FAM-392 & Metagabbro & 5.3 \\
ASP-221 & Gabbro & 9.2 \\
VCA-1007 & Gabbro & 8.2 \\
FAM-176 & Diorite dike & 6.7 \\
FAM-213 & Tonalite & 7.7 \\
FAM-332 & Hybrid & 9.9 \\
FAM339 & Migmatite & 10.6 \\
FAM391 & Migmatite & 13.8 \\
\hline
\end{tabular}

Note: SMOW-standard mean ocean wáter 
long. Grains of spinel-hercynite solid solution composition (with $\sim 50 \%$ of each end member) form fine symplectic intergrowths with amphibole. Similar metagabbro samples were described from the nearby Sierra de Valle Fértil (Baldo et al., 1999; Gallien et al., 2012).

Gabbro grades from coarse to fine grained with an assemblage mainly formed of plagioclase (from 48 to 32 modal \%) and amphibole (from $58 \%$ to $47 \%$ ). Coarse-grained rocks have large (up to $5 \mathrm{~cm}$ ) poikilitic anhedral to subhedral crystals of hornblende with inclusions of plagioclase. Cumulate texture is present in places. Fine-grained gabbro samples exhibit magmatic hypidiomorphic granular texture. Microprobe analyses show that amphibole is magnesiohornblende according to the scheme of Hawthorne et al. (2012). Plagioclase crystals range from $\mathrm{An}_{94}$ to $\mathrm{An}_{85}$. The hornblendeplagioclase pairs analyzed in the coarse-grained type $\left[\mathrm{Mg} /\left(\mathrm{Mg}+\mathrm{Fe}^{2+}\right)=0.72\right.$ and $\mathrm{An}=93$; average from six samples] and in the fine-grained rock $\left[\mathrm{Mg} /\left(\mathrm{Mg}+\mathrm{Fe}^{2+}\right)=0.63\right.$ and $\mathrm{An}=87$; average from five samples] show slight variations in their compositions. Magnetite and ilmenite occur as euhedral to subhedral crystals in both varieties.

\subsection{Pod- and Dike-Like Mafic Bodies}

The typical rock in these bodies consists of plagioclase + quartz + biotite + hornblende and shows a magmatic hypidiomorphic granular texture. Titanite, epidote, and opaque minerals are accessories. No differences in mineral composition were found between the dikes and pod-like mafic bodies. Plagioclase is zoned, with slightly altered, Ca-rich cores (up to An 70) and sodic rims (up to $A n \sim 50$ ). Anhedral potassic feldspar grains $\left(\mathrm{Or}_{93} \mathrm{Ab}_{5} \mathrm{An}_{2}\right)$ are very scarce. Most amphibole grains are magnesiohornblende to pargasite according to Hawthorne et al. (2012). Titanite contains some $\mathrm{Al}$ and $\mathrm{Fe}^{3+}(\sim 1$ wt $\%$ of each, as oxide).

\section{WHOLE-ROCK GEOCHEMISTRY}

\subsection{Major and Minor Elements}

\subsubsection{Amphibolite}

Amphibolite samples (Table 1; Fig. 2) show a restricted range of $\mathrm{SiO}_{2}(50-54 \mathrm{wt} \%)$ and $\mathrm{Mg}$-number $[\mathrm{Mg} \#=100 \times \mathrm{MgO} /(\mathrm{MgO}+$ $\mathrm{FeO}^{*}$ ) molar] of 60-69 (except for sample FAM320, a stoped block in the tonalite, which had Mg\# = 49). The most mafic compositions correspond to samples of nematoblastic texture. In the total alkali-silica (TAS) diagram (not shown), all the samples are classified as basalt and basaltic andesite and are meta- luminous (ASI [aluminum saturation index] = 0.59-0.79). Concentrations of Cs (0.3-1.0 ppm), Rb (7.4-16 ppm), Ba (54-137 ppm), and Sr (94-177 ppm) in these rocks are relatively low and show a restricted range in samples from tabular- and lens-shaped bodies, whereas samples from stoped blocks display higher values $(\mathrm{Cs}=2.3, \mathrm{Rb}=63, \mathrm{Ba}=135$, and $\mathrm{Sr}=179$ ppm). High field strength elements (HFSEs) are mostly low, with $\mathrm{Nb}<5$, $\mathrm{Ta}<0.4$, and $\mathrm{Zr}<$ $94 \mathrm{ppm}$. Concentrations of other immobile elements, such as Y (11-29 ppm) and Cr (68-980 ppm), are highly variable. Rare earth element (REE) concentrations normalized to chondrite show flat patterns $\left(\mathrm{La}_{\mathrm{N}} / \mathrm{Yb}_{\mathrm{N}}=1.9-3.6\right)$ with negligible or small negative Eu anomaly $\left(\mathrm{Eu}_{\mathrm{N}} / \mathrm{Eu}_{\mathrm{N}}{ }^{*}=0.86-0.97\right.$; not shown $)$.

\subsubsection{Metagabbro and Gabbro}

Metagabbro and gabbro samples have low $\mathrm{SiO}_{2}$ content (45-49 wt\%), are metaluminous (ASI $=0.70-0.84)$, and have $\mathrm{Mg} \#$ values ranging from 59 to 70 (Table 1; Fig. 2). They plot in the gabbro field on the TAS diagram modified for plutonic rocks (not shown).

Concentrations of mobile elements, such as $\mathrm{Cs}(<1 \mathrm{ppm}), \mathrm{Rb}(<10 \mathrm{ppm}), \mathrm{Ba}(<58 \mathrm{ppm}), \mathrm{Th}$ $(<1 \mathrm{ppm})$, and $\mathrm{Pb}(<13 \mathrm{ppm})$, are low, except for sample FAM321 from a stoped metagabbro block, which had higher contents of Cs (7 ppm), $\mathrm{Rb}$ (123 ppm), and Ba (169 ppm). Strontium ranges from 140 to $166 \mathrm{ppm}$. Concentrations of both HFSEs and immobile elements are low (Nb $<3$ ppm, Ta $<0.2 \mathrm{ppm}, \mathrm{Zr}<25 \mathrm{ppm}, \mathrm{Y}$ $<11, \mathrm{Cr}<311$, and $\mathrm{Co}<50$ ppm). REE contents normalized to chondrite show flat patterns $\left(\mathrm{La}_{\mathrm{N}} / \mathrm{Yb}_{\mathrm{N}}=1.4-2.4\right)$ with positive to very slightly negative $\mathrm{Eu}$ anomalies $\left(\mathrm{Eu}_{\mathrm{N}} / \mathrm{Eu}^{*}{ }_{\mathrm{N}}=\right.$ 0.97-1.38; not shown).

\subsubsection{Gabbro and Diorite Pod- and Dike-Like Bodies}

Two samples were analyzed, one from a dike and one from a pod-like body (Table 1; Fig. 2). They have different $\mathrm{SiO}_{2}$ contents (46 and 54 wt $\%$ ) and low Mg\# values (45 and 51). They plot in the gabbro field on the TAS diagram modified for plutonic rocks (not shown). They are metaluminous $(\mathrm{ASI} \approx 0.75$ ).

Large ion lithophile elements (LILEs) are found in relatively low concentrations ( $\mathrm{Cs}<$ 2 ppm, $\mathrm{Rb}<48$ ppm, Ba $<329$ ppm, Th $<6$ $\mathrm{ppm}$, and $\mathrm{Pb}<10 \mathrm{ppm})$. The strontium content is intermediate (202 and 235 ppm). Concentrations of both HFSEs and immobile elements are low ( $\mathrm{Nb}<8$ ppm, $\mathrm{Ta}<1.1 \mathrm{ppm}, \mathrm{Zr}<101 \mathrm{ppm}$, $\mathrm{Y}<27, \mathrm{Cr}<82$, and $\mathrm{Co}<53$ ppm). REE contents normalized to chondrite give relatively flat patterns $\left(\mathrm{La}_{\mathrm{N}} / \mathrm{Yb}_{\mathrm{N}} \sim 4\right)$ with weak negative $\mathrm{Eu}$ anomalies $\left(\mathrm{Eu}_{\mathrm{N}} / \mathrm{Eu}^{*}{ }_{\mathrm{N}} \sim 0.8\right.$; not shown).

\subsection{Isotope Geochemistry}

\subsection{1. $\mathrm{Rb}$-Sr and Sm-Nd Isotopic Compositions}

A reference age of $481 \mathrm{Ma}$ for calculating the isotope compositions of the samples at the time of metamorphism/magmatism is based on the weighted U-Pb SHRIMP zircon age of sample FAM7086, a hybrid rock from the intermediate zone of the Cerro Toro aureole (Dahlquist et al., 2008; Alasino et al., 2014). Ten amphibolite samples from Cerro Asperecito yielded ${ }^{87} \mathrm{Sr} /{ }^{86} \mathrm{Sr}_{\mathrm{t}}$ values between 0.7063 and 0.7122 and $\varepsilon_{\mathrm{Nd}}(\mathrm{t})$ values from +0.3 to -5.0 (Table 2; Fig. 2). The olivine metagabbro sample yielded ${ }^{87} \mathrm{Sr} /{ }^{86} \mathrm{Sr}_{\mathrm{t}}=0.70816$ and $\varepsilon_{\mathrm{Nd}}(\mathrm{t})=-2.2$, and a sample from the small pod-like gabbro body yielded ${ }^{87} \mathrm{Sr} /{ }^{86} \mathrm{Sr}_{\mathrm{t}}=0.7068$ and $\varepsilon_{\mathrm{Nd}}(\mathrm{t})=-3.7$ (Table 2; Fig. 2). Dahlquist and Galindo (2004) reported values of ${ }^{87} \mathrm{Sr} /{ }^{86} \mathrm{Sr}_{\mathrm{t}}=0.70686$ and $\varepsilon_{\mathrm{Nd}}(\mathrm{t})=-5.8$ for a hornblende-gabbro body (VCA7037) from the same region (Fig. 2).

The negative $\varepsilon_{\mathrm{Nd}}(\mathrm{t})$ values indicate a crustal contribution to the parent magmas, which could have been incorporated in the source, or during ascent or emplacement. The calculated depleted mantle model ages $\left(\mathrm{T}_{\mathrm{DM}}\right.$; Table 2 ) vary from $1.2 \mathrm{Ga}$ to $1.8 \mathrm{Ga}$, indicating that the crustal source contributing the Nd was Mesoproterozoic or older; model ages assuming pre-Ordovician crustal residence are even more consistent at $1.2-1.6 \mathrm{Ga}$. Such uniformity is unlikely to arise from random degrees of mixing or contamination with a much older component, suggesting that the crustal material involved was indeed Mesoproterozoic.

\subsubsection{Oxygen Isotope Composition}

Eight samples from Cerro Toro aureole were analyzed (Table 3; Fig. 2). Two gabbro samples, the dike, and the tonalite yielded normal $\delta^{18} \mathrm{O}$ values between $+6.7 \%$ and $+9.2 \%$ o typical of unaltered igneous rocks (e.g., Hoefs, 2009). The olivine-pyroxene metagabbro was significantly depleted in ${ }^{18} \mathrm{O}\left(\delta^{18} \mathrm{O}=+5.3 \%\right)$. On the other hand, the hybrid rock and the migmatite samples yielded $\delta^{18} \mathrm{O}$ values significantly higher, between $+9.9 \%$ and $+13.8 \%$ o.

\section{EMPLACEMENT PRESSURE- TEMPERATURE $(P-T)$ VALUES}

Emplacement $P-T$ values were obtained from a hornblende gabbro (samples ASP221 and VCA7037) from Cerro Asperecito applying the Holland and Blundy (1994) hornblende-plagioclase geothermometer and the Al-in-hornblende geobarometer (Johnson and Rutherford, 1989). Mean chemical values from rims of hornblende and plagioclase in apparent textural equilibrium 
Alasino et al.

(Table DR2 [see footnote 1]) yielded high temperatures of $960 \pm 40{ }^{\circ} \mathrm{C}(\mathrm{ASP} 221)$ and $785 \pm$ $40{ }^{\circ} \mathrm{C}$ (VCA7037), and a pressure of $\sim 4.7 \mathrm{kbar}$ (Table 4). The significant temperature difference between the two samples from the same body is also reflected in textural variations (see section 4.2), suggesting different cooling rates. Emplacement conditions of the Cerro Toro tonalite of $785 \pm 40{ }^{\circ} \mathrm{C}$ and $5.4 \pm 0.5$ kbar (Alasino et al., 2014) are consistent with the values found here. Moreover, this pressure estimate is consistent with the garnet-absent coronitic assemblage in the metagabbro, which formed earlier and probably at greater depth than the gabbro from which samples ASP221 and VCA7037 were collected (e.g., Baldo et al., 1999; Gallien et al., 2012), but in any case at pressures below $~ 8$ kbar (Otamendi et al., 2010; Tibaldi et al., 2013).

\section{DISCUSSION}

Field relations in the study area suggest that metagabbro, amphibolite, and gabbro are the oldest intrusive rocks, with the tonalite and post-tonalite mafic dikes being slightly younger. The older mafic rocks mostly form numerous sills that intruded the high-grade metasedimentary rocks. Moreover, they commonly occur as screens and stoped blocks in the tonalite (Fig. 2; section 2.2). A hybrid tonalite from the Cerro Toro aureole was dated at $481 \pm 4 \mathrm{Ma}$ (Dahlquist et al., 2008; Alasino et al., 2014). On the other hand, the pod- and dike-like bodies (of gabbro and diorite composition) that intrude and are commonly mingled with the tonalite are younger. A sample of hornblende gabbro (VCA1007) in the study area, showing mingling relationship with tonalite, was dated at $468 \pm 4 \mathrm{Ma}$ (Pankhurst et al., 2000). Similar timing relationships for mafic rocks also have been reported in other regions of the Sierras Pampeanas, such as Sierra de Los Llanos and Sierra de Valle Fértil (e.g., Pankhurst et al., 1998, 2000; Otamendi et al., 2009, 2012; Ducea et al., 2010). U-Pb zircon ages from the Sierra de Valle Fértil (Pankhurst et al., 2000; Ducea et al., 2010) are consistent with our proposed age difference: The older mafic unit was dated at $478 \pm 4$ and $484 \pm$ $8 \mathrm{Ma}$, and the pod- and dike-like bodies of hornblende gabbro in the tonalite unit were dated at $474 \pm 4 \mathrm{Ma}$. The large tonalite intrusions are widespread and relatively restricted in time (mostly between ca. 480 and $470 \mathrm{Ma}$; e.g., Ducea et al., 2010). Additionally, at Las Chacras, one of the most westerly parts of the Famatinian magmatic arc, garnet amphibolite is interbedded with paragneiss metamorphosed under high-pressure upper amphibolite facies

TABLE 4. GEOTHERMOBAROMETRY FOR HORNBLENDE GABBRO OF THE CERRO ASPERECITO

\begin{tabular}{|c|c|c|c|}
\hline \multirow[b]{2}{*}{ Calibration method } & \multirow[b]{2}{*}{ Mineral assemblage } & \multicolumn{2}{|c|}{$P$ - $T$ values } \\
\hline & & $\begin{array}{c}T \\
\left({ }^{\circ} \mathrm{C}\right)\end{array}$ & $\begin{array}{c}P \\
\text { (kbar) }\end{array}$ \\
\hline \multicolumn{4}{|l|}{ Sample ASP-221* } \\
\hline $\begin{array}{l}\text { Holland and Blundy (1994) } \\
\text { Johnson and Rutherford (1989) }\end{array}$ & $\begin{array}{l}\text { Hbl-Pl } \\
\text { Al-in-Hbl }\end{array}$ & $963 \pm 40$ & $4.7 \pm 0.5$ \\
\hline \multicolumn{4}{|l|}{$\underline{\text { Sample VCA-7037 }}^{\dagger}$} \\
\hline $\begin{array}{l}\text { Holland and Blundy (1994) } \\
\text { Johnson and Rutherford (1989) }\end{array}$ & $\begin{array}{l}\mathrm{Hbl}-\mathrm{Pl} \\
\text { Al-in-Hbl }\end{array}$ & $785 \pm 40$ & $4.6 \pm 0.5$ \\
\hline \multicolumn{4}{|c|}{$\begin{array}{l}\text { Note: For mineral chemical data, see supplementary data Table DR2 (see text footnote } 1 \text { ). Hbl-hornblende; } \\
\mathrm{Pl} \text {-plagioclase; Al—aluminum; } P \text {-pressure; } T \text {-temperature. } \\
{ }^{*} \text { Average composition of plagioclase (analysis numbers } 13,20,29 \text {, and } 30 \text { ) and hornblende (analysis } \\
\text { numbers } 14 \text { and } 21 \text { ). } \\
{ }^{\dagger} \text { Average composition of plagioclase (analysis numbers } 26 \text { and } 28 \text { ) and hornblende (analysis numbers } 4,5 \text {, } \\
\text { and 25). }\end{array}$} \\
\hline
\end{tabular}

(Casquet et al., 2012a). The paragneiss contains Ordovician (ca. $468 \mathrm{Ma}$ ) igneous zircon grains with rims having similar metamorphic ages, pointing to an age of ca. $468 \mathrm{Ma}$ for the mafic protolith. Thus, in the Famatinian magmatic arc, we can distinguish: (1) an older (pre- to syntonalitic intrusion) mafic suite of amphibolite, metagabbro, and hornblende-gabbro, and (2) a younger (syntonalitic intrusion) mafic suite dominated by dike- and pod-like bodies of gabbro and diorite composition and to a lesser extent amphibolite (e.g., Las Chacras area). Next, we explore the geochemical and isotopic characteristics of these groups of mafic rocks considering other outcrops in the western Sierras Pampeanas (i.e., Sierras de Famatina, Valle Fértil, and Los Llanos; these are summarized in Table DR1 [see footnote 1], with published sources). Additionally, data from some locations in the Puna region (e.g., the western Puna eruptive belt and the Pocitos igneous complex) are also considered.

\subsection{Source of the Famatinian Mafic Magmas}

\subsubsection{Geochemical Constraints: Major- and Trace-Element Compositions}

Discrimination diagrams such as $\mathrm{SiO}_{2}$ versus $\mathrm{FeO} * / \mathrm{MgO}$ (Fig. 4A) show that $\sim 60 \%$ of the samples, dominated by the older mafic suite, are tholeiitic; the remaining samples are transitional into the calc-alkaline field (see also DeBari, 1994; Otamendi et al., 2012). Similarly the $\mathrm{K}_{2} \mathrm{O}$ versus $\mathrm{SiO}_{2}$ diagram shows that the older mafic rocks are tholeiitic, and samples of the younger group fall in the calc-alkaline and high-K calc-alkaline fields (Fig. 4B). Majorelement versus $\mathrm{Mg}$-number (Mg\#) diagrams exhibit some correlations, including increasing $\mathrm{TiO}_{2}$ and decreasing $\mathrm{CaO}$ with decreasing $\mathrm{Mg \#}$, suggesting a compositional continuum in the mafic samples (Fig. 5). Clearly, the older mafic suite is more primitive (higher $\mathrm{Mg \#}$ ) with lower $\mathrm{Ti}$ and higher $\mathrm{Al}$ contents than the younger suite.
Enrichment in LILEs is seen in many stoped blocks of both amphibolitic and gabbroic rocks hosted in the tonalite (Table 1), suggesting some transfer of these elements from the tonalitic magma. Moreover, the overall analyses $(\sim 50)$ have $\mathrm{Ba} / \mathrm{Nb}$ (average $=38$, minimum $=10$, maximum $=265$ ) and $\mathrm{Th} / \mathrm{Nb}$ (average $=0.62$; minimum $=0.05$, maximum $=3.6$ ) exceeding the typical ranges for normal $(\mathrm{N})$-type midocean-ridge basalt $(\mathrm{MORB} ; \mathrm{Ba} / \mathrm{Nb}=1.7-8.0$ and $\mathrm{Th} / \mathrm{Nb}=0.002-0.06$; Saunders et al., 1988). Involvement of upper-crustal and/or pelagic sediment in their petrogenesis could generate such enrichment. However, considering the Th and $\mathrm{Nb}$ contents (after normalization to $\mathrm{Y}$ content, to minimize the effect of fractionation in mantle-derived magmas; Saunders et al., 1988), most early gabbro and amphibolite samples exhibit low $\mathrm{Th} / \mathrm{Y}$ ratio, suggesting that a crustal component was minimal in the source (Fig. 4C; e.g., Pankhurst et al., 1998). Additionally, the older mafic suite also shows relative depletion of $\mathrm{Rb}$ (Fig. 4D). On the other hand, the younger gabbroic samples show similar trace-element compositions to pelagic sediments, thus implying a larger crustal component (Fig. 4D). The same differences between both suites of mafic rocks are seen in the N-MORB-normalized trace-element diagram (Fig. 6). Younger gabbros on average show enrichment in LILEs and Th relative to the older mafic rocks; along with the differences in $\mathrm{Nb}$-Ta patterns, this may correspond to a subduction signature (GLOSS [Global subducted sediment composition]; Plank and Langmuir, 1998).

\subsubsection{Sr-Nd-O Isotope Variations}

In agreement with other geochemical trends (see section 7.1.1), the ${ }^{87} \mathrm{Sr} /{ }^{86} \mathrm{Sr}_{\mathrm{t}}$ versus $\mathrm{P}_{2} \mathrm{O}_{5} / \mathrm{K}_{2} \mathrm{O}$ plot suggests that the mafic samples were not significantly affected by contamination with the Ordovician metasedimentary host rocks (Fig. 7A). The $\mathrm{P}_{2} \mathrm{O}_{5} / \mathrm{K}_{2} \mathrm{O}$ ratio (e.g., Hart et al., 1997) for silicic composition crustal rocks is low, generally, lower than 0.1 , 
Mafic rocks of the Ordovician Famatinian magmatic arc
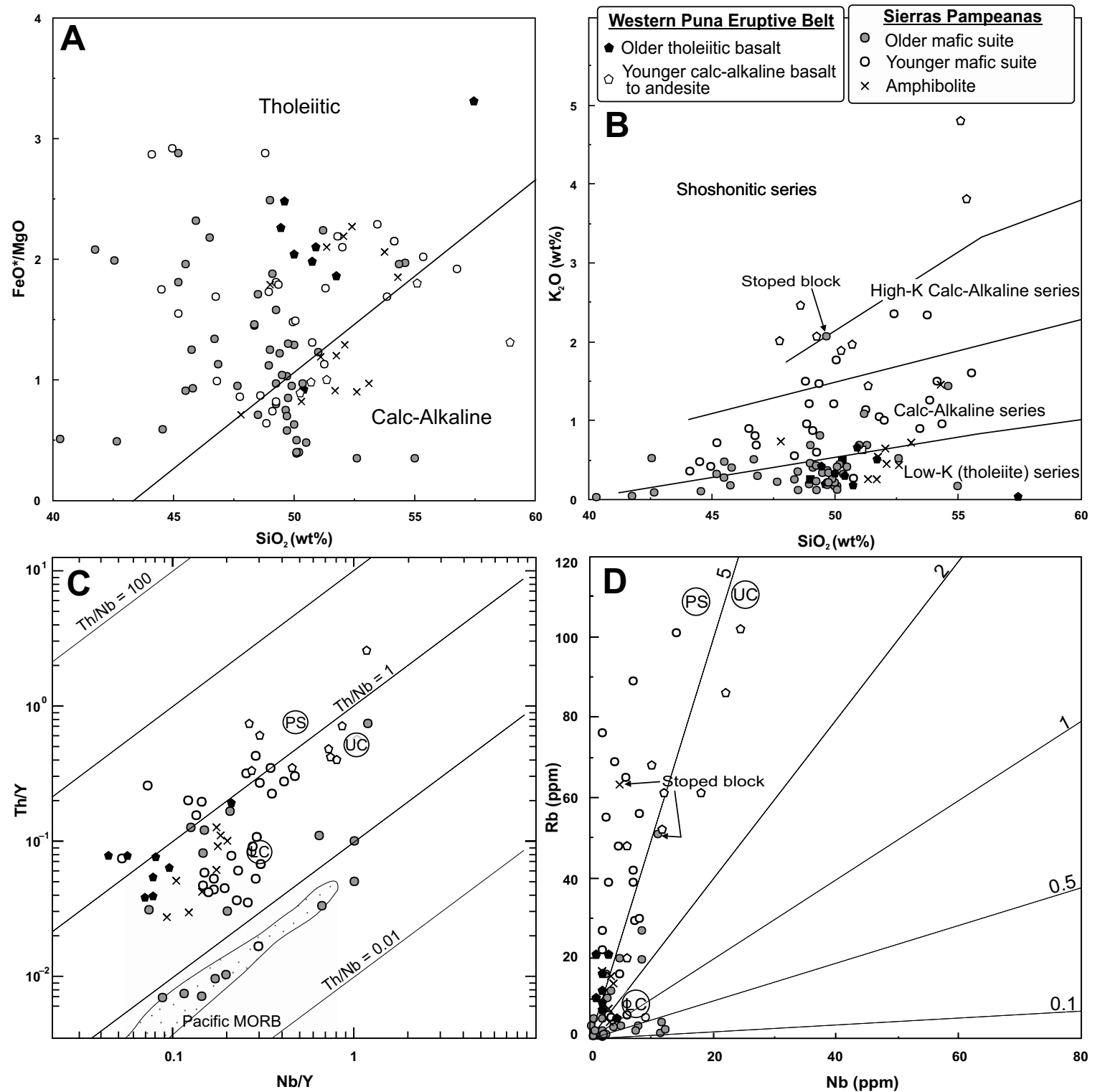

Figure 4. (A) $\mathrm{SiO}_{2}$ vs. $\mathrm{FeO}^{*} / \mathrm{MgO}$, (B) $\mathrm{SiO}_{2}$ vs. $\mathrm{K}_{2} \mathrm{O}$, (C) $\mathrm{Nb} / \mathrm{Y}$ vs. $\mathrm{Th} / \mathrm{Y}$ and (D) $\mathrm{Nb}$ vs. $\mathrm{Rb}$ for old and young mafic rocks of the Famatinian arc. Average values for lower crust (LC), upper crust (UC), and pelagic sediment (PS) are from Taylor and McLennan (1985). MORB-mid-ocean-ridge basalt.

while mantle-derived magmas typically have relatively high $\mathrm{P}_{2} \mathrm{O}_{5} / \mathrm{K}_{2} \mathrm{O}$ ratios. Decreasing $\mathrm{P}_{2} \mathrm{O}_{5} / \mathrm{K}_{2} \mathrm{O}$ values along with an increase in ${ }^{87} \mathrm{Sr} /{ }^{86} \mathrm{Sr}_{t}$ ratio are expected for mafic magmas mixing with crustal materials. This behavior is not significant in the mafic samples of this study. Moreover, $\varepsilon_{\mathrm{Nd}}(\mathrm{t})$ values between +5 and -6 of the mafic samples are largely uncorrelated with the Mg\# values (Fig. 7B), suggesting that crystal fractionation did not play a significant role in magma diversification.

Pelitic migmatites show higher $\delta^{18} \mathrm{O}$ values $(+10.6 \%$ and $+13.8 \%$ o $)$ typical of sedimentary rocks that have interacted with meteoric waters at low temperatures (Hoefs, 2009). All igne- ous samples from gabbro to tonalite analyzed here gave $\delta^{18} \mathrm{O}$ values between $+5.3 \%$ and $+9.9 \%$, within the normal range for unaltered igneous compositions as reported by Hoefs (2009). The lowest value of $+5.3 \%$ (FAM392, an old metagabbro) and that of $+6.7 \%$ o for a dike (i.e., young gabbroic rocks) are typical of juvenile magmas (Harmon and Hoefs, 1995), whereas the remaining samples (including one gabbro $=9.2 \%$, one diorite dike $=8.2 \%$, and one tonalite $=7.7 \%$ o ) have higher $\delta^{18} \mathrm{O}$ values typical of continental arc magmas. Moreover, one hybrid rock in the Cerro Toro thermal aureole yielded an oxygen composition close to those of the migmatites $(+9.9 \%$ o), suggesting assimilation of metasedimentary rocks through partial melting during emplacement of tonalitic magmas (Alasino et al., 2014).

As shown already, the mafic samples do not show evidence for significant middle- or uppercrustal contamination, but they have a wide range of $\delta^{18} \mathrm{O}$ values from $+5.3 \%$ o to $+9.2 \%$ o Involvement of slab-derived components in the mantle source do not seem applicable as both the higher and lower $\delta^{18} \mathrm{O}$ values are in samples of the older gabbros, and only the younger mafic rocks show the chemical enrichments ascribable to subduction (see previous section). Moreover, peridotite xenoliths from modern subduction zones do not show $\delta^{18} \mathrm{O}$ values higher than that 

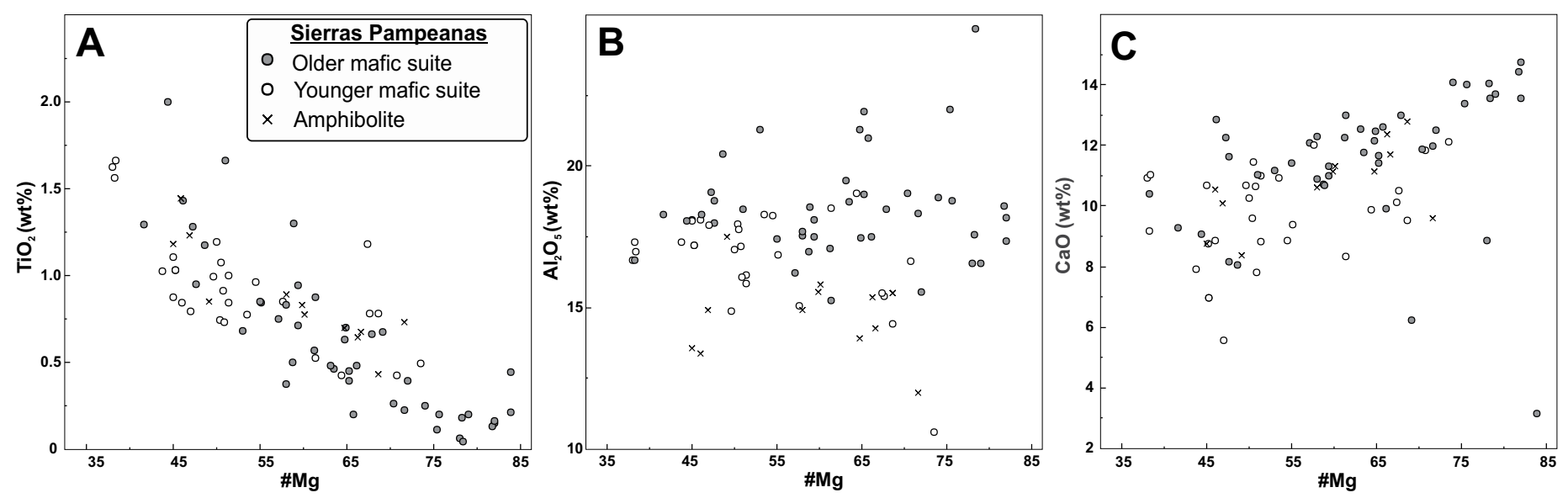

Figure 5. Whole-rock compositions of $(\mathrm{A}) \mathrm{TiO}_{2},(\mathrm{~B}) \mathrm{Al}_{2} \mathrm{O}_{3}$, and (C) $\mathrm{CaO}$ against $\mathrm{Mg}$ number for mafic samples from the $\mathrm{Famatinian}$ orogen. $\mathrm{Mg}$ number $(\# \mathrm{Mg})=\left[100 \times \mathrm{MgO} /\left(\mathrm{MgO}+\mathrm{FeO}^{*}\right)\right]$ molar.

of the upper mantle of $5.18 \% \circ \pm 0.28 \%$ (Mattey et al., 1994; Eiler, 2001; Chin et al., 2014; Liu et al., 2014). In conclusion, although some fractionation and interaction with the continental crust are clearly unavoidable, a metasomatized old subarc lithospheric mantle ( \pm lower crust) with ${ }^{18} \mathrm{O}$-enriched signatures (e.g., $8.03 \%$ \pm $0.28 \%$; Liu et al., 2014) was probably involved in the origin of these magmas by mixing with melts generated by asthenospheric mantle upwelling.

\subsection{Western Puna Eruptive Belt}

The Puna (NW Argentina), one of the largest high-altitude plateau on Earth, consists in part of Famatinian rocks (e.g., Palma et al., 1986; Allmendinger et al., 1997; Kay and Coira, 2009). A suite of mafic magmatic rocks in the western Puna eruptive belt $\left(22^{\circ} \mathrm{S}-26^{\circ} \mathrm{S}\right)$ records two distinctive volcano-sedimentary sequences (Coira et al., 2009): (1) older mafic rocks consisting of ca. 485 Ma tholeiitic basalt in Pinato-Lari and Quebrada Honda, and (2) ca. 470 Ma calc-alkaline basalt to andesite from Huaitiquina, Aguada de la Perdiz, and Sierra de Guayaos (see Fig. 1 in Coira et al., 2009). Their geochemical characteristics (see Figs. 4 and 6) are similar to the Sierras Pampeanas samples studied here, suggesting common petrogenetic processes (see Ducea et al., 2015). Nd-isotope data for calcalkaline basalt to andesite samples from the Puna (Bierlein et al., 2006) compare well with those for the younger gabbroic rocks studied here, with ${ }^{143} \mathrm{Nd} /{ }^{144} \mathrm{Nd}_{\mathrm{t}}=0.51195-0.51216$ and $\mathrm{T}_{\mathrm{DM}}=0.9-1.2 \mathrm{Ga}$.

\subsection{Famatinian Mafic Magmas and their Link with Contemporaneous Silicic Magmas}

In contrast to the mafic rocks, the more silicic rocks, from tonalite to granite, contain a significant proportion of inherited zircon (e.g., Ducea
Figure 6. Normal mid-oceanridge basalt (N-MORB)-normalized (Saunders and Tarney, 1984) trace-element variation plots showing the average compositions of mafic samples from the Famatinian arc $(n=$ number of samples). GLOSS (dotted line) is the global average subducted sediment composition for large ion lithophile elements and Nb-Ta (Plank and Langmuir, 1998). Averages are from Table DR1 (see text footnote 1 ).

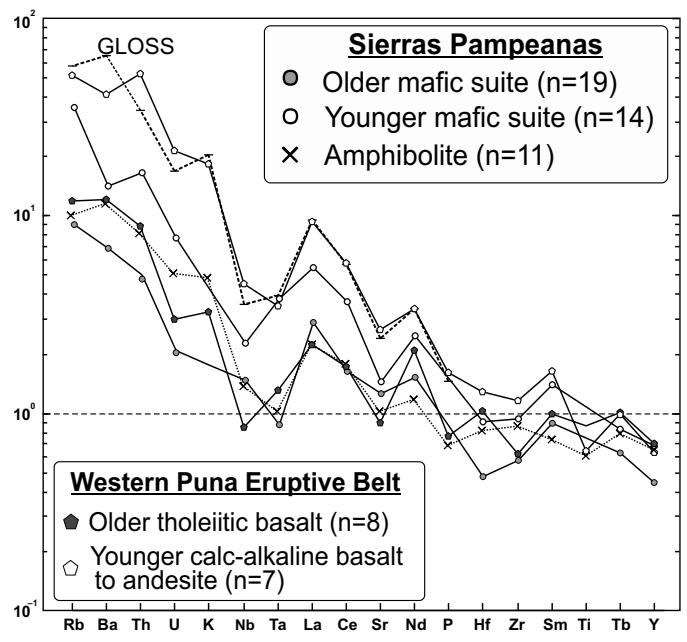

et al., 2010). A compilation of zircon inheritance ages in tonalite and granodiorite shows two main clusters: Mesoproterozoic-Early Neoproterozoic (ca. 1150-850 Ma) and Neoproterozoic-Early Cambrian (ca. 720-530 Ma). Hence, mixing of mantle-sourced magmas with crustal granitic melts is very probable (e.g., Otamendi et al., 2012; Ducea et al., 2015). However, a plot of ${ }^{143} \mathrm{Nd} /{ }^{144} \mathrm{Nd}_{\mathrm{t}}$ against $\mathrm{SiO}_{2}$ (Fig. 8A) shows the existence of two major suites of rocks in the Famatinian arc. The first and larger suite has low ${ }^{143} \mathrm{Nd} /{ }^{144} \mathrm{Nd}_{\mathrm{t}}$ values (mostly $<0.5120$ ). This suite includes gabbro, tonalite, granodiorite, and monzogranite of the Sierras Pampeanas and the Puna (e.g., the Macon granitoids; ${ }^{40} \mathrm{Ar} /{ }^{39} \mathrm{Ar}$ on hornblende: $483 \pm 8 \mathrm{Ma}$; Koukharsky et al., 2002), together with Famatinian migmatite and related melts (leucogranitoids; Otamendi et al., 2012; Alasino et al., 2014). The second suite, with ${ }^{143} \mathrm{Nd} /{ }^{144} \mathrm{Nd}_{\mathrm{t}}$ values $>0.5120$, is represented by amphibolite, a few older gabbros of the Sierras Pampeanas, and calc-alkaline basalt to andesite of the western Puna eruptive belt and some intermediate to silicic rocks such as (1) the Pocitos plutonic complex in the southern Puna plateau (476 \pm 2 Ma; Kleine et al., 2004) and (2) the Peñón granite in the Sierra de Umango (473 \pm 17 Ma; Varela et al., 2003).

Within the first suite, the role of mafic magmas in the generation of tonalite by mixing with supracrustal material is not straightforward. The mixing plot of ${ }^{87} \mathrm{Sr} /{ }^{86} \mathrm{Sr}$ against $\mathrm{Sr}$ (Fig. 8B), which includes gabbro and diorite, tonalitegranodiorite, and metasedimentary rocks (migmatite), reveals that the old gabbroic rocks were not involved in the generation of the intermediate magmas. Although old gabbroic rocks have mean ${ }^{87} \mathrm{Sr} /{ }^{86} \mathrm{Sr}$ values similar to a hypothetical mafic end member, they have lower Sr contents (mostly $\mathrm{Sr} \leq 200$ ppm; Fig. 8B). In fact, most of 

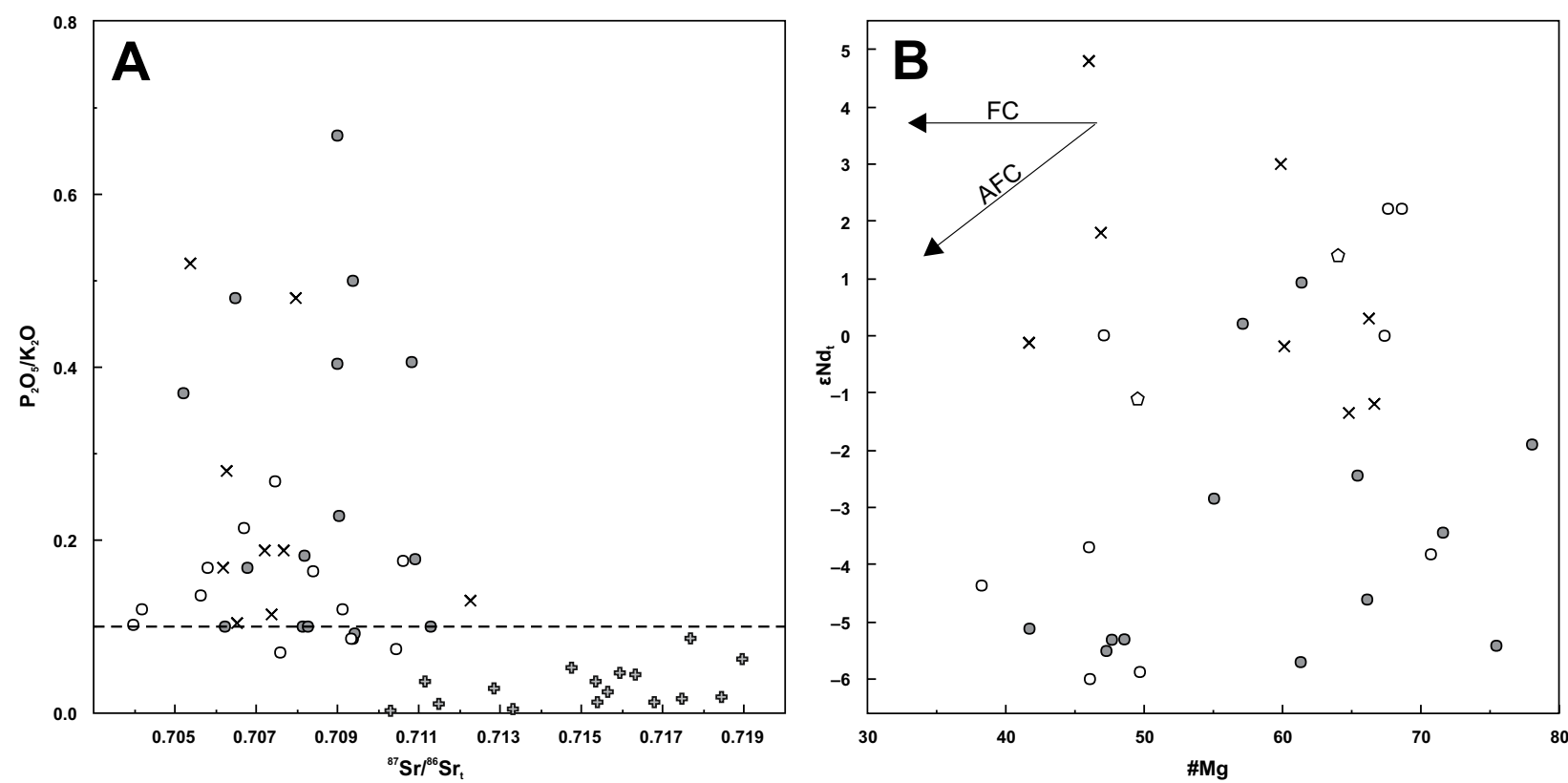

Figure 7. (A) ${ }^{87} \mathrm{Sr} /{ }^{86} \mathrm{Sr}_{\mathrm{t}}$ vs. $\mathrm{P}_{2} \mathrm{O}_{5}$ and (B) Mg-number (Mg\#) vs. epsilon $\mathrm{Nd}\left[\varepsilon_{\mathrm{Nd}}(\mathrm{t})\right]$ as indicators of intermediate and felsic crust contamination and fractional crystallization (FC) and assimilation-fractional crystallization (AFC), respectively. Ordovician metasedimentary rocks are from Sierra de Famatina and Sierra de Valle Fértil (Casquet et al., 2012a; Otamendi et al., 2012; Alasino et al., 2014).

the young mafic rocks $(\mathrm{Sr} \sim 330 \mathrm{ppm})$ plot close to the hypothetical mafic end member. Remarkably, the compositions of amphibole in the intermediate rocks (tonalite-granodiorite) are similar to those of the younger mafic rocks but clearly distinct from the composition of amphibole in the older gabbroic rocks (Fig. 9).

\subsection{New Insights into the Evolution of Magmas in the Famatinian Arc}

This work reveals that in the Early and Middle Ordovician, the crust of the proto-Andean margin of Gondwana experienced a progressive geochemical shift in the mafic magma compositions. The earlier suite consists mainly of tholeiitic to calc-alkaline rocks (with relatively high LREEs, Rb, Ba, Th, and U compared to $\mathrm{N}-\mathrm{MORB}$, and without a negative Eu anomaly); these rocks may represent near-primary liquids. The second suite is calc-alkaline with an arc signature enriched in LILEs, and it may indicate addition of a subduction component.

The $\mathrm{Zn} / \mathrm{Fe}_{\mathrm{T}}$ ratio is insensitive to olivineand orthopyroxene-melt fractionation, but it is strongly sensitive to the involvement of garnet or clinopyroxene during melting (Lee et al., 2010). Our mafic samples (older and younger mafic suites) have a wide range in $\mathrm{Zn} / \mathrm{Fe}_{\mathrm{T}}\left(\times 10^{4}\right)$ values (Fig. 10A). Some samples are similar to typical mantle peridotite and basaltic melts generated from sources dominated by olivine- orthopyroxene ( $\sim \pm 1$; Le Roux et al., 2010; Lee et al., 2010), while others have higher values $(12-15$, some even $>30)$ expected for sources dominated by clinopyroxene \pm garnet (Figs. 10A and 10B). In fact, samples with $\mathrm{Zn} / \mathrm{Fe}_{\mathrm{T}}\left(\times 10^{4}\right)<10$ (mostly younger mafic rocks; Fig. 10B) have $\delta^{18} \mathrm{O}$ values typical of MORB $\left(\delta^{18} \mathrm{O}=5.18 \% \circ \pm 0.28 \%\right.$ o $)$, whereas those with higher $\mathrm{Zn} / \mathrm{Fe}_{\mathrm{T}}$ values (older gabbros) have higher $\delta^{18} \mathrm{O}$ values $(\sim 9 \%)$, reflecting sources with dominant clinopyroxene \pm garnet (e.g., old lithospheric pyroxenite; e.g., Ducea et al., 2013; Lee, 2014; Liu et al., 2014; Murray et al., 2015). The Hf/Sm ratio is also related to the presence of garnet in the source (van Westrenen et al., 2011). Our rocks show a wide range of $\mathrm{Hf} / \mathrm{Sm}$ values: The young gabbros and amphibolites have values that scatter around that of peridotite $(0.78)$, whereas the older gabbroic rocks are closer to that of garnet pyroxenite (0.4; Fig. $10 \mathrm{C}$ ), in agreement with low and high $\delta^{18} \mathrm{O}$ values, respectively. This evidence suggests that a garnet pyroxenite source was dominant for the older mafic rocks (excluding most of the amphibolite samples), whereas peridotite was significant in the younger mafic suite. All the mafic rocks have a relatively restricted range of Sr (100-400 ppm) but highly variable Y (1-60 $\mathrm{ppm})$, the latter being partitioned into garnet at high pressure; this leads to contrasting values of $\mathrm{Sr} / \mathrm{Y}$, with most of the old mafic rocks showing the higher values (Fig. 10D).
Finally, the more-evolved Nd-isotope compositions correlate with higher values of $\mathrm{Zn} / \mathrm{Fe}_{\mathrm{T}}$ that can be attributed to mixing between pyroxenite- and peridotite-derived melts (Fig. 10E), whereas amphibolite samples with low $\mathrm{Zn} / \mathrm{Fe}_{\mathrm{T}}$ values and isotopically less evolved $\mathrm{Nd}$-isotopic composition were probably generated from peridotite-dominated sources. The high values of $\mathrm{Zn} / \mathrm{Fe}_{\mathrm{T}}$ in some samples show no correlation with Nd isotopes; one sample (SVF-577) in this group with negative $\varepsilon_{\mathrm{Hf}}(t)$ in zircon (average of -5.3; Dahlquist et al., 2013) indicates crustal assimilation during or prior to zircon crystallization.

\subsection{Tectonic Implications for the Famatinian Arc}

A conceptual model for the possible origin of the Famatinian mafic magmas and their link with contemporaneous intermediate to silicic magmas throughout the arc is shown in Figure 11. Otamendi et al. (2012) envisaged a pre-arc crust $\sim 30 \mathrm{~km}$ thick for the Famatinian orogen, with half of this consisting of sedimentary sequences, although this is probably a minimum overall inasmuch as the Mesoproterozoic basement that formed the root of the arc is not exposed. Earlier mafic magmas represented by numerous dikes and sills in these high-grade metasedimentary rocks (e.g., Mannheim and Miller, 1996; Otamendi et al., 2012; Alasino et al., 


\section{Alasino et al.}
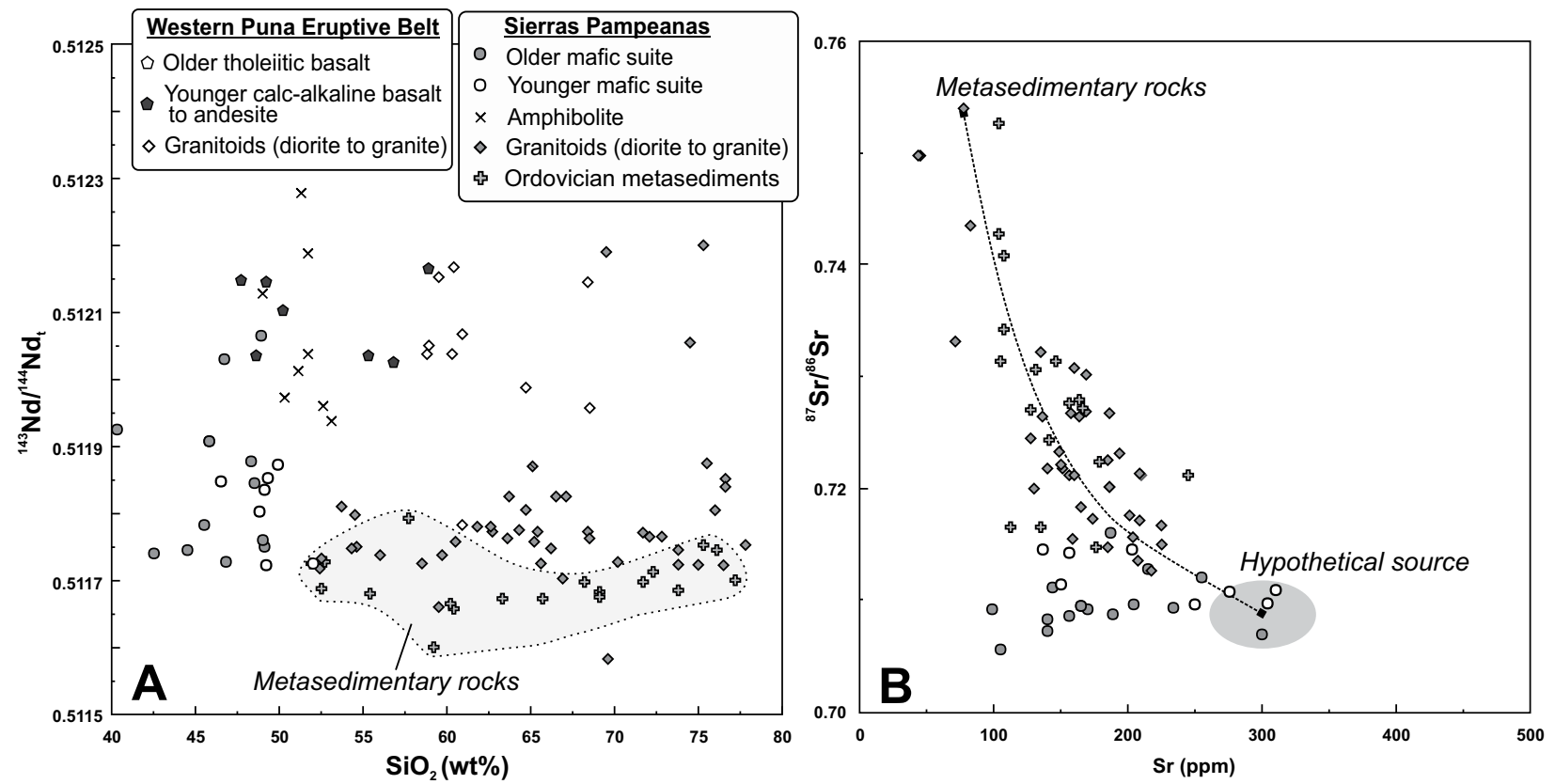

Figure 8. (A) $\mathrm{SiO}_{2}$ vs. ${ }^{143} \mathrm{Nd} /{ }^{144} \mathrm{Nd}_{\mathrm{t}}$ for igneous and metamorphic rocks of the Famatinian orogen (for references, see Table DR1 [see text footnote 1]). (B) $\mathrm{Sr}$ vs. ${ }^{87} \mathrm{Sr} /{ }^{86} \mathrm{Sr}$ for igneous and Ordovician metasedimentary rocks of the Sierras Pampeanas. Ordovician metasedimentary rocks are from Sierra de Famatina and Sierra de Valle Fértil (Casquet et al., 2012a; Otamendi et al., 2012, Alasino et al., 2014).

2014) increased the geothermal gradient and promoted partial melting (migmatization) in the crust (Otamendi et al., 2012). Subsequently, the input of dioritic and tonalitic magmas promoted widespread anatexis of crustal protoliths, generating hybrid rocks (e.g., Otamendi et al., 2012; Alasino et al., 2014; Ducea et al., 2015). Granodioritic to monzogranitic plutons emplaced at shallow crustal levels formed through the interaction between crustal melts and tonalite (or their differentiates; e.g., Otamendi et al. 2012). Some silica-rich $\left(>70 \% \mathrm{SiO}_{2}\right)$ rocks cannot be related to this hybrid origin as they are isotopically less evolved and slightly younger (by a few million years) than the tonalites, suggesting that these uncontaminated magmas evolved from different magma batches. The younger mafic rocks were emplaced contemporaneously with the tonalitic intrusions, forming numerous dikeand pod-like bodies that mingled with the host granitoid magma.

The progressive shift from a pyroxenite subcontinental mantle to an asthenospheric peridotite mantle source through time (over 20 m.y.) produced melts that mixed in varied proportions. Partial melting of subcontinental pyroxenite was probably followed by upwelling of the asthenospheric mantle resulting from foundering of the former (Fig. 11). This process produced earlier melts that were isotopically evolved and had little contribution from juvenile peridotite melts (the latter only being evident in the amphibolite rocks), followed by isotopically depleted melts resulting from extensive melting of peridotite in the late stages of the arc. Pyroxenite starts melting 35-40 km deeper than an upwelling peridotite diapir by adiabatic decompression (e.g., Pertermann and Hirschmann, 2003). A pos- sible model for magma formation would imply foundering of the subcontinental pyroxenite mantle and partial melting producing tholeiitic melts, with a progressive shift to calc-alkaline melts (with subduction signature and increasing $\mathrm{H}_{2} \mathrm{O}$ ) resulting from adiabatic decompression of upwelling mantle wedge peridotite (Fig. 11).

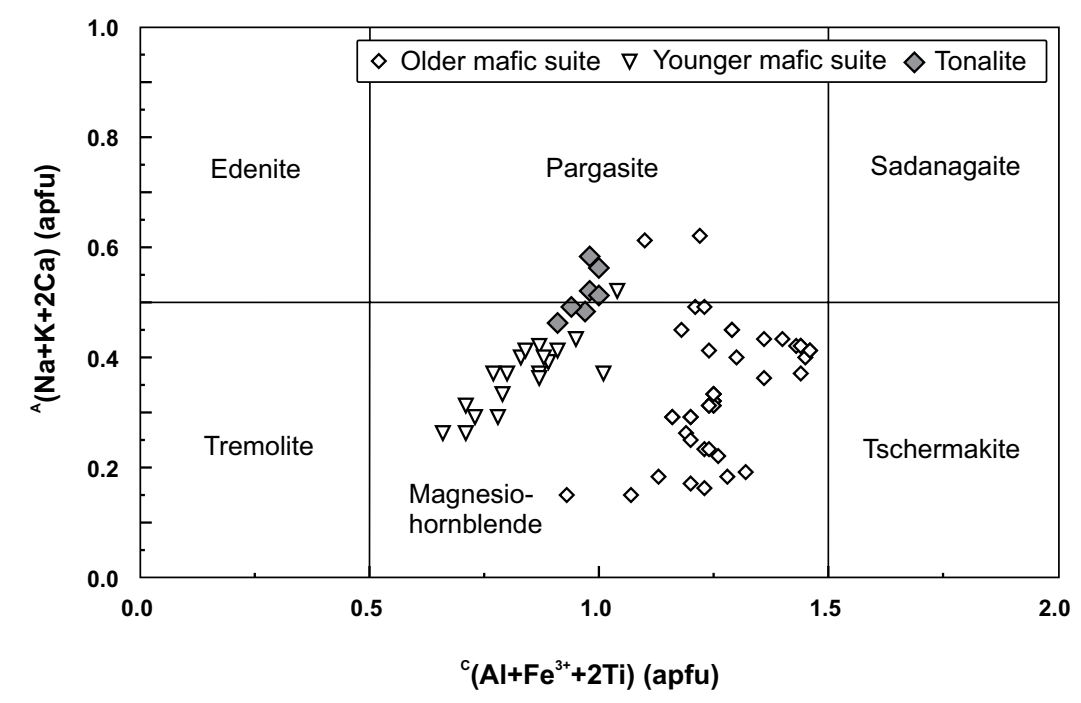

Figure 9. Ca-amphibole classification (Hawthorne et al., 2012) for tonalite and mafic samples from Sierras de Famatina, Valle Fértil, and Chepes. Data are from Dahlquist et al. (2005b), Otamendi et al. (2008), and this study. 
Mafic rocks of the Ordovician Famatinian magmatic arc
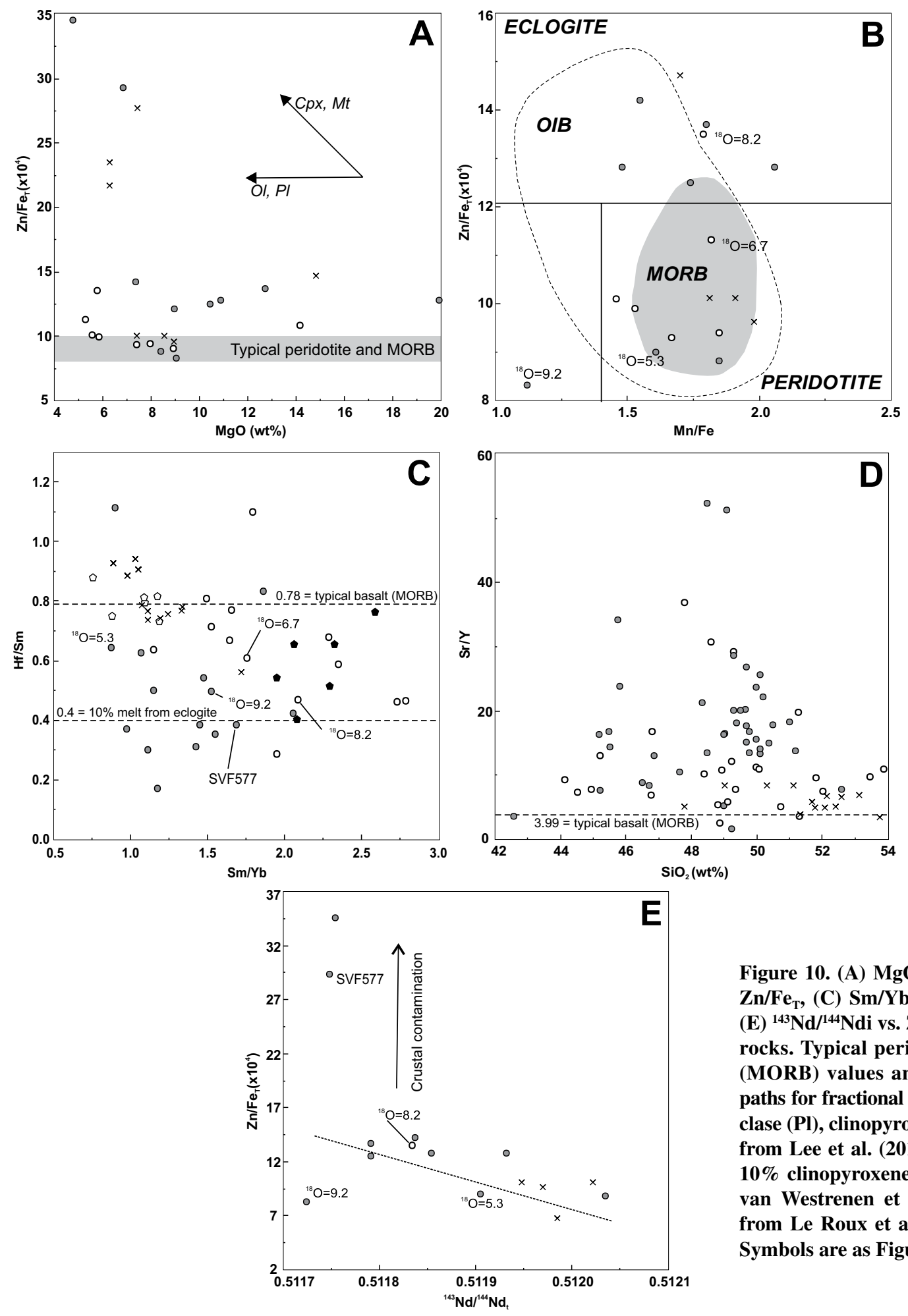

Figure 10. (A) $\mathrm{MgO}$ vs. $\mathrm{Zn} / \mathrm{Fe}_{\mathrm{T}}\left(\times 10^{4}\right)$, (B) $\mathrm{Mn} / \mathrm{Fe}_{\mathrm{T}}$ vs. $\mathrm{Zn} / \mathrm{Fe}_{\mathrm{T}}$, (C) $\mathrm{Sm} / \mathrm{Yb}$ vs. $\mathrm{Hf} / \mathrm{Sm}$, (D) $\mathrm{SiO}_{2}$ vs. Sr/Y, and (E) ${ }^{143} \mathrm{Nd} /{ }^{144} \mathrm{Ndi}$ vs. $\mathrm{Zn} / \mathrm{Fe}_{\mathrm{T}}\left(\times 10^{4}\right)$ for Famatinian mafic rocks. Typical peridotite and mid-ocean-ridge basalt (MORB) values and vectors showing melt evolution paths for fractional crystallization of olivine (OI), plagioclase (PI), clinopyroxene (Cpx), and magnetite (Mt) are from Lee et al. (2010). $\mathrm{Hf} / \mathrm{Sm}$ values of chondrite and $10 \%$ clinopyroxene (cpx) + garnet (grt) melt are after van Westrenen et al. (2011). Diagrams are modified from Le Roux et al. (2010) and Murray et al. (2015). Symbols are as Figure 8. OIB-oceanic-island basalt.

\section{CONCLUSIONS}

Field, geochemical, and isotopic data for mafic rocks of the western Sierra de Famatina (at $29^{\circ} \mathrm{S}$ ) define two contrasting suites, which can be correlated with similar suites elsewhere in the Sierras Pampeanas (e.g., Sierra de Vale Fértil and Sierra de Los Llanos):

(1) Amphibolite, hornblende gabbro, and minor olivine-(ortho)pyroxene metagabbro formed sheeted plutons of varied thickness that intruded high-grade metasedimentary rocks. Mafic rocks of this suite are commonly found within the voluminous tonalite intrusions, either as rafts or stoped blocks and in places mingled, indicating that they are pre- to syntonalite. The geochemical features of mafic stoped blocks were partially modified by interaction with more felsic magmas. 


\section{Alasino et al.}
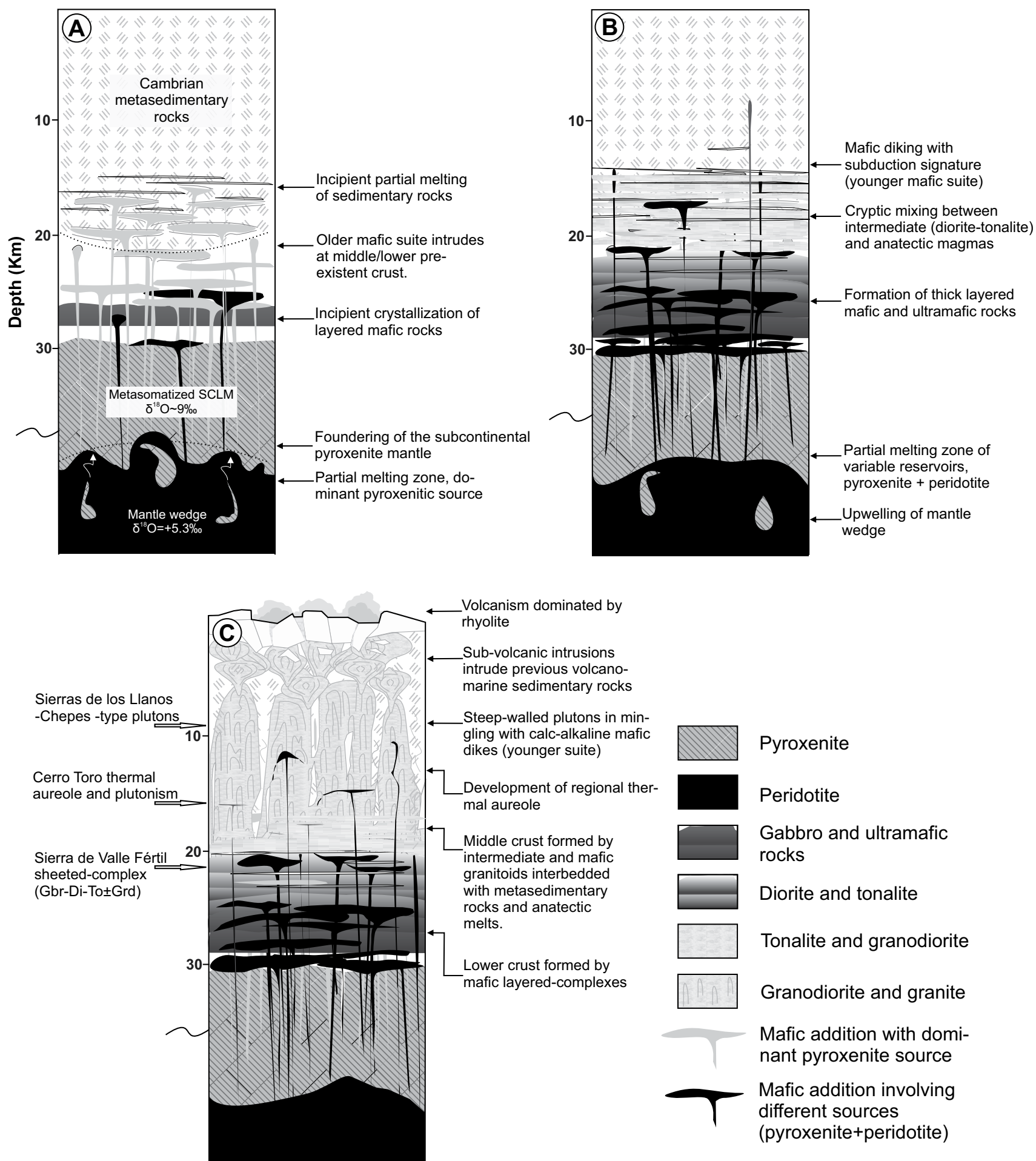

Figure 11. Conceptual model for the generation of the mafic magmas of the Famatinian orogen and their link with contemporaneous intermediate and silicic magmas based on Otamendi et al. (2012) and this study. (A) Early magmatic activity, and older mafic suite intruded at lower crust; this pulse is dominated by tholeiitic mafic plutonic rocks generated from metasomatized subcontinental lithospheric mantle (SCLM; pyroxenite) by lithospheric removal with restricted asthenospheric mantle input (e.g., amphibolite). (B) Upwelling and adiabatic decompression melting of peridotite mantle and mixing with pyroxenite melts; increase in mafic diking in the crust belonging to the younger mafic suite. Generation and emplacement of intermediate magmas and subsequent contamination with crustal materials. (C) Coalescence of intermediate to silicic magmas at middle and upper levels. The correspondence between depth of the arc and the plutonic/volcanic outcrops at several localities across the western part of the Sierras Pampeanas is also shown. Mineral abbreviations: Gbr-gabbro; Di-diorite; To—tonalite; Grd-granodiorite. 
(2) Dikes and minor mafic bodies intruded the tonalites. These usually show mingling relationships with the tonalite magma, indicating that they were contemporaneous.

Chemically, the first suite is tholeiitic to calcalkaline, whereas the second is calc-alkaline. Our new data, together with those previously published, suggest that during the Famatinian orogeny, mafic magmatism underwent changes largely coeval with the intrusion of voluminous tonalite-granodiorite magmas (ca. 480$470 \mathrm{Ma})$. The earlier mafic suite consisted of pre- to syntonalite mafic magmas of tholeiitic to calc-alkaline signature that were isotopically evolved. The later suite of syntonalite mafic intrusions was both calc-alkaline with subduction-related chemistry and isotopically more juvenile than the first.

Petrogenesis of the mafic rocks involved progressive mixing of different isotopic reservoirs. Pyroxenite ( \pm garnet) was probably the dominant source of the earlier gabbroic magmas (with little contribution from peridotite melts represented mostly by amphibolite samples), whereas peridotite dominated in the younger ones. This change in source provides an explanation for the shift toward more juvenile compositions through time (over 20 m.y.). We hypothesize that pyroxenite-derived melts, i.e., melts sourced in the subcontinental mantle of the arc, were followed by more primitive melts resulting from upwelling of the mantle wedge peridotite after lithospheric foundering. According to this interpretation, lithospheric foundering was coeval with the high-heat-flux event (i.e., tonalitic magmatism) in the arc.

\section{ACKNOWLEDGMENTS}

Funds were provided by an Argentinean grant PICT-2013 0472 and by Spanish grants CGL200907984 and GR58/08 Universidad Complutense de Madrid-Santander. P.H. Alasino thanks Carlos Bustamante and Sergio de La Vega for technical support. We thank J.E. Otamendi (Universidad Nacional de Río Cuarto) and an anonymous reviewer for their very constructive reviews that significantly improved the manuscript. We also would like to thank C. Koeberl (science editor) and S. Barr (associate editor) for their comments and suggestions to our manuscript.

\section{REFERENCES CITED}

Alasino, P.H., Casquet, C., Larrovere, M.A., Pankhurst, R.J. Galindo, C., Dahlquist, J.A., Baldo, E.G., and Rapela, C.W., 2014, The evolution of a mid-crustal thermal aureole at Cerro Toro, Sierra de Famatina, NW Argentina: Lithos, v. 190-191, p. 154-172, doi:10.1016/j .lithos.2013.12.006

Allmendinger, R.W., Jordan, T.E., Kay, S.M., and Isacks, B.L., 1997, The evolution of the Altiplano-Puna Plateau of the central Andes: Annual Review of Earth and Planetary Sciences, v. 25, p. 139-174, doi:10.1146 /annurev.earth.25.1.139.

Bahlburg, H., and Hervé, F., 1997, Geodynamic evolution and tectonostratigraphic terranes of northwestern Argentina and northern Chile: Geological Society of
America Bulletin, v. 109, p. 869-884, doi:10.1130 /0016-7606(1997)109<0869:GEATTO>2.3.CO; 2.

Baldo, E.G., Murra, J.A., Casquet, C., Galindo, C., and Saavedra, J., 1999, El gabro coronítico de la Sierra de Valle Fértil, Sierras Pampeanas Argentina: Condiciones $P-T$ de la etapa coronítica: Boletín de la Sociedad Española de Mineralogía, v. 22-A, p. 17-18.

Bierlein, F.P., Stein, H.J., Coira, B., and Reynolds, P., 2006 , Timing of gold and crustal evolution of the Palaeozoic south central Andes, NW Argentina-Implications for the endowment of orogenic belts: Earth and Planetary Science Letters, v. 245, p. 702-721, doi:10.1016/j.epsl .2006.03.019

Borthwick, J., and Harmon, R.S., 1982, A note regarding $\mathrm{ClF}_{3}$ as an alternative to $\mathrm{BrF}_{5}$ for oxygen isotope analysis: Geochimica et Cosmochimica Acta, v. 46, p. 16651668, doi:10.1016/0016-7037(82)90321-0.

Casquet, C., Rapela, C.W., Pankhurst, R.J., Baldo, E.G., Galindo, C., Fanning, C.M., and Dahlquist, J.A., 2012a, Fast sediment underplating and essentially coeval juvenile magmatism in the Ordovician margin of Gondwana, western Sierras Pampeanas, Argentina: Gondwana Research, v. 22, p. 664-673, doi:10.1016/j gr.2012.05.001.

Casquet, C., Rapela, C.W., Pankhurst, R.J., Baldo, E.G., Galindo, C., Fanning, C.M., Dahlquist, J.A., and Saavedra, J., 2012b, A history of Proterozoic terranes in southern South America: From Rodinia to Gondwana: Geoscience Frontiers, v. 3, p. 137-145, doi:10.1016/j .gsf.2011.11.004.

Chernicoff, C.J., Zappettini, E.O., Santos, J.O.S., Allchurch, S., and McNaughton, N.J., 2010, The southern segment of the Famatinian magmatic arc, La Pampa Province, Argentina: Gondwana Research, v. 17, p. 662-675, doi:10.1016/j.gr.2009.10.008

Chin, E.J., Lee, C.-T.A., and Barnes, J.D., 2014, Thickening, refertilization, and the deep lithosphere filter in continental arcs: Constraints from major and trace elements and oxygen isotopes: Earth and Planetary Science Letters, v. 397, p. 184-200, doi:10.1016/j.eps1.2014.04 .022 .

Clayton, R.N., and Mayeda, T.K., 1963, The use of bromine pentafluoride in the extraction of oxygen from oxides and silicates for isotopic analysis: Geochimica et Cosmochimica Acta, v. 27, p. 43-52, doi:10.1016/0016 $-7037(63) 90071-1$

Coira, B., Koukharsky, M., Ribeiro Guevara, S., and Cisterna, C.E., 2009, Puna (Argentina) and northern Chile Ordovician basic magmatism: A contribution to the tectonic setting: Journal of South American Earth Sciences, v. 27, p. 24-35, doi:10.1016/j.jsames.2008.10.002.

Collo, G., Astini, R.A., Cawood, P.A., Buchan, C., and Pimentel, M., 2009, U-Pb detrital zircon ages and $\mathrm{Sm}-\mathrm{Nd}$ isotopic features in low-grade metasedimentary rocks of the Famatina belt: Implications for late Neoproterozoic-early Palaeozoic evolution of the protoAndean margin of Gondwana: Journal of the Geological Society of London, v. 166, p. 303-319, doi:10.1144 /0016-76492008-051.

Cristofolini, E.A., Otamendi, J.E., Ducea, M.N., Pearson, D.M., Tibaldi, A.M., and Baliani, I., 2012, Detrital zircon U-Pb ages of metasedimentary rocks from Sierra de Valle Fértil: Entrapment of Middle and Late Cambrian marine successions in the deep roots of the Early Ordovician Famatinian arc: Journal of South American Earth Sciences, v. 37, p. 77-94, doi:10.1016/j.jsames 2012.02.001

Dahlquist, J.A., and Galindo, C., 2004, Geoquímica isotópica de los granitoides de la sierra de Chepes: Un modelo geotectónico y termal, implicancias para el orógeno famatiniano: Revista de la Asociación Geológica Argentina, v. 59, p. 57-69.

Dahlquist, J.A., Rapela, C.W., and Baldo, E.G., 2005a, Cordierite-bearing S-type granitoids in the Sierra de Chepes (Sierras Pampeanas): Petrogenetic implications: Journal of South American Earth Sciences, v. 20, p. 231-251, doi:10.1016/j.jsames.2005.05.014

Dahlquist, J.A., Rapela, C.W., Pankhurst, R.J., Baldo, E., Saavedra, J., and Alasino, P.H., 2005b, Los granitoides de la sierra de Chepes y su comparación con granitoides paleozoicos de las Sierras Pampeanas: Implicancias para el orógeno Famatiniano, in Dahlquist, J.A., Baldo, E., and Alasino, P.H., eds., Geología de la Provincia de La Rioja Precámbrico-Paleozoico Inferior: Revista de la Asociación Geológica Argentina Serie Especial 8, p. 87-108.

Dahlquist, J.A., Galindo, C., Pankhurst, R.J., Rapela, C.W., Alasino, P.H., Saavedra, J., and Fanning, C.M., 2007, Magmatic evolution of the Peñón Rosado granite: Petrogenesis of garnet-bearing granitoids: Lithos, v. 95, p. 177-207, doi:10.1016/j.lithos.2006.07.010.

Dahlquist, J.A., Pankhurst, R.J., Rapela, C.W., Galindo, C., Alasino, P., Fanning, C.M., Saavedra, J., and Baldo, E., 2008, New SHRIMP U-Pb data from the Famatina complex: Constraining Early-Mid-Ordovician Famatinian magmatism in the Sierras Pampeanas, Argentina: Geologica Acta, v. 6, p. 319-333.

Dahlquist, J.A., Pankhurst, R.J., Gaschnig, R.M., Rapela, C.W., Casquet, C., Alasino, P.H., Galindo, C., and Baldo, E.G., 2013, Hf and Nd isotopes in Early Ordovician to Early Carboniferous granites as monitors of crustal growth in the proto-Andean margin of Gondwana: Gondwana Research, v. 23, p. 1617-1630, doi: 10.1016/j.gr.2012.08.013

DeBari, S., 1994, Petrogenesis of the Fiambalá gabbroic intrusion, northwestern Argentina, a deep crustal syntectonic pluton in a continental magmatic arc: Journal of Petrology, v. 35, p. 679-713, doi:10.1093/petrology 135.3.679.

De Paolo, D.J., Linn, A.M., Schubert, G., 1991, The continental crustal age distribution: methods of determining mantle separation ages from $\mathrm{Sm}-\mathrm{Nd}$ isotopic data and application to the Southwestern United States: Journal of Geophysical Research, v. 96, p. 2071-2088, doi:10 1029/90JB02219.

Ducea, M.N., Otamendi, J.E., Bergantz, G., Stair, K.M., Valencia, V.A., and Gehrels, G.E., 2010, Timing constraints on building an intermediate plutonic arc crustal section: U-Pb zircon geochronology of the Sierra Valle Fértil-La Huerta, Famatinian arc, Argentina: Tectonics, v. 29, p. 21-22, doi:10.1029/2009TC002615.

Ducea, M.N., Seclaman, A.C., Murray, K.E., Jianu, D., and Schoenbohm, L.M., 2013, Mantle-drip magmatism beneath the Altiplano-Puna Plateau, Central Andes: Geology, v. 41, p. 915-918, doi:10.1130/G34509.1.

Ducea, M.N., Otamendi, J.E., Bergantz, G.W., Jianu, D., and Petrescu, L., 2015, The origin and petrologic evolution of the Ordovician Famatinian-Puna arc, in DeCelles, P.G., Ducea, M.N., Carrapa, B., and Kapp, P.A., eds., Geodynamics of a Cordilleran Orogenic System: The Central Andes of Argentina and Northern Chile: Geological Society of America Memoir 212, p. 125-138, doi:10.1130/2015.1212(07).

Eiler, J.M., 2001, Oxygen isotope variations of basaltic lavas and upper mantle rocks: Reviews in Mineralogy and Geochemistry, v. 43, p. 319-364, doi:10.2138/gsrmg 43.1.319.

Gallien, F., Mogessie, A., Hauzenberger, C.A., Bjerg, E., Delpino, S., and Castro De Machuca, B., 2012, On the origin of multi-layer coronas between olivine and plagioclase at the gabbro-granulite transition, Valle FértilLa Huerta Ranges, San Juan Province, Argentina: Journal of Metamorphic Geology, v. 30, p. 281-302, doi:10.1111/j.1525-1314.2011.00967.x

Grosse, P., Bellos, L.I., de los Hoyos, C.R., Larrovere, M.A., Rossi, J.N., and Toselli, A.J., 2011, Across-arc variation of the Famatinian magmatic arc (NW Argentina) exemplified by I-, S- and transitional I/S-type Early Ordovician granitoids of the Sierra de Velasco: Journal of South American Earth Sciences, v. 32, p. 110-126, doi:10.1016/j.jsames.2011.03.014.

Gutierrez-Alonso, G., Murphy, J.B., Fernández-Suárez, J., Weil, A.B., Franco, M.P., and Gonzalo, J.P., 2011, Lithospheric delamination in the core of Pangea: Sm-Nd insights from the Iberian mantle: Geology, v. 39 , p. $155-158$, doi:10.1130/G31468.1.

Harmon, R.S., and Hoefs, J., 1995, Oxygen isotope heterogeneity of the mantle deduced from global ${ }^{18} \mathrm{O}$ systematics of basalts from different geotectonic settings: Contributions to Mineralogy and Petrology, v. 120, p. 95-114, doi:10.1007/BF00311010.

Hart, W.K., Carlson, R.W., and Shirey, S.B., 1997, Radiogenic Os in primitive basalts from the northwestern U.S.A.: Implications for petrogenesis: Earth and Planetary Science Letters, v. 150, p. 103-116, doi:10.1016 /S0012-821X(97)00075-7. 
Hawthorne, F.C., Oberti, R., Harlow, G.E., Maresch, W.V., Martin, R.F., Shumacher, J.C., and Welch, M.D., 2012, IMA report nomenclature of the amphibole supergroup: The American Mineralogist, v. 97, p. 20312048, doi:10.2138/am.2012.4276.

Hoefs, J., 2009, Stable Isotope Geochemistry: Berlin, Springer-Verlag, $285 \mathrm{p}$

Holland, T.J.B., and Blundy, J.D., 1994, Non-ideal interactions in calcic amphiboles and their bearing on amphibole-plagioclase thermometry: Contributions to Mineralogy and Petrology, v. 116, p. 433-447, doi:10 .1007/BF00310910.

Hongn, F., Tubía, J.M., Esteban, J.J., Aranguren, A., Vegas, N., Sergeev, S., Larionov, A., and Basei, M., 2014, The Sierra de Cachi (Salta, NW Argentina): Geological evidence about a Famatinian retro-arc at mid crustal levels: Journal of Iberian Geology, v. 40, p. 225-240, doi:10.5209/rev_JIGE.2014.v40.n2.45303.

Johnson, D.M., Hooper, P.R., and Conrey, R.M., 1999, XRF analysis of rocks and minerals for major and trace elements on a single low dilution Li-tetraborate fused bead: Advances in X-Ray Analysis, v. 41, p. 843-867.

Johnson, M.C., and Rutherford, M.J., 1989, Experimental calibration of the aluminum-in-hornblende geobarometer with application to Long Valley caldera (California) volcanic rocks: Geology, v. 17, p. 837-841, doi:10 $.1130 / 0091-7613(1989) 017<0837$ :ECOTAI $>2.3 . C O ; 2$.

Jordan, T.E., and Allmendinger, R.W., 1986, The Sierras Pampeanas of Argentina: A modern analogue of Rocky Mountain foreland deformation: American Journal of Science, v. 286 , p. $737-764$, doi:10.2475/ajs.286.10 .737 .

Kay, R.W., and Kay, S.M., 1993, Delamination and delamination magmatism: Tectonophysics, v. 219 , p. 177 189, doi:10.1016/0040-1951(93)90295-U.

Kay, S.M., and Coira, B.L., 2009, Shallowing and steepening subduction zones, continental lithospheric loss, magmatism, and crustal flow under the central Andean Altiplano-Puna Plateau, in Kay, S.M., Ramos, V.A and Dickinson, W.R., eds., Backbone of the Americas: Shallow Subduction, Plateau Uplift, and Ridge and Terrane Collision: Geological Society of America Memoir 204, p. 229-259, doi:10.1130/2009.1204(11).

Kay, S.M., Coira, B., and Viramonte, J., 1994, Young mafic back arc volcanic rocks as indicators of continental lithospheric delamination beneath the Argentine Puna Plateau, central Andes: Journal of Geophysical Research, v. 99, p. 24,323-24,339, doi:10.1029 194JB00896.

Kleine, T., Mezger, K., Zimmermann, U., Münker, C., and Bahlburg, H., 2004, Crustal evolution along the Early Ordovician proto-Andean margin of Gondwana: Trace element and isotope evidence from the complejo ígneo Pocitos (northwestern Argentina): The Journal of Geology, v. 112, p. 503-520, doi:10.1086/422663.

Koukharsky, M.L., Quenardelle, S., Litvak, V., Maisonnave, E.B., and Page, S., 2002, Plutonismo del ordovícico inferior en el sector Norte de la sierra de Macon, provincia de Salta: Revista de la Asociación Geológica Argentina, v. 57, p. 173-181.

Lee, C.-T.A., 2014, Physics and chemistry of deep continental crust recycling, in Holland, H., and Turekian, K., eds., Treatise on Geochemistry (2nd ed.), Volume 4 Elsevier, p. 423-456, doi:10.1016/B978-0-08-095975 $-7.00314-4$.

Lee, C.-T.A., Luffi, P., Le Roux, V., Dasgupta, R., Albarede, F., and Leeman, W.P., 2010, The redox state of arc mantle using $\mathrm{Zn} / \mathrm{Fe}$ systematics: Nature, v. 468, p. 681-685, doi:10.1038/nature09617.

Le Roux, V., Lee, C.-T.A., and Turner, S.J., 2010, Zn/Fe systematics in mafic and ultramafic systems: Implications for detecting major element heterogeneities in the Earth's mantle: Geochimica et Cosmochimica Acta, v. 74, p. 2779-2796, doi:10.1016/j.gca.2010.02.004.

Liu, C.-Z., Wu, F.-Y., Chung, S.-L., Sun, W.-D., and Ji, W.Q., 2014, A 'hidden' 18O-enriched reservoir in the sub-arc mantle: Scientific Reports, v. 4, p. 4232, doi: 10 $.1038 /$ srep04232

Mannheim, R., and Miller, H., 1996, Las rocas volcánicas y subvolcánicas eopaleozoicas del Sistema de Fama- tina, in Aceñolaza, F., Miller, H., and Toselli, A., eds., Geología del Sistema de Famatina: Münchner Geologische Hefte 19A, p. 159-186.

Manthei, C.D., Ducea, M.N., Girardi, J.D., Patchett, P.J., and Gehrels, G.E., 2010, Isotopic and geochemical evidence for a recent transition in mantle chemistry beneath the western Canadian Cordillera: Journal of Geophysical Research, v. 115, p. B02204, doi:10.1029 12009JB006562.

Mattey, D., Lowry, D., and Macpherson, C., 1994, Oxygen isotope composition of mantle peridotite: Earth and Planetary Science Letters, v. 128, p. 231-241, doi:10 .1016/0012-821X(94)90147-3.

Murray, K.E., Ducea, M.N., and Schoenbohm, L., 2015, Foundering-driven lithospheric melting: The source of central Andean mafic lavas on the Puna Plateau $\left(22^{\circ} \mathrm{S}-\right.$ $27^{\circ} \mathrm{S}$ ), in DeCelles, P.G., Ducea, M.N., Carrapa, B., and Kapp, P.A., eds., Geodynamics of a Cordilleran Orogenic System: The Central Andes of Argentina and Northern Chile: Geological Society of America Memoir 212, p. 139-166.

Otamendi, J.E., Tibaldi, A.M., Vujovich, G.I., and Viñao, G.A., 2008, Metamorphic evolution of migmatites from the deep Famatinian arc crust exposed in Sierras Valle Fértil-La Huerta, San Juan, Argentina: Journal of South American Earth Sciences, v. 25, p. 313-335, doi: 10.1016/j.jsames.2007.09.001.

Otamendi, J.E., Ducea, M.N., Tibaldi, A.M., Bergantz, G., de la Rosa, J.D., and Vujovich, G.I., 2009, Generation of tonalitic and dioritic magmas by coupled partial melting of gabbroic and metasedimentary rocks within the deep crust of the Famatinian magmatic arc, Argentina: Journal of Petrology, v. 50, p. 841-873, doi:10 .1093/petrology/egp022.

Otamendi, J.E., Cristofolini, E., Tibaldi, A.M., Quevedo, F., and Baliani, I., 2010, Petrology of mafic and ultramafic layered rocks from the Jaboncillo Valley, Sierra de Valle Fértil, Argentina: Implications for the evolution of magmas in the lower crust of the Famatinian arc: Journal of South American Earth Sciences, v. 29, p. 685-704, doi:10.1016/j.jsames.2009.11.001.

Otamendi, J.E., Ducea, M.N., and Bergantz, G.W., 2012, Geological, petrological and geochemical evidence for progressive construction of an arc crustal section, Sierra de Valle Fértil, Famatinian Arc, Argentina: Journal of Petrology, v. 53, p. 761-800, doi:10.1093 /petrology/egr079.

Palma, M.A., Parica, P.D., and Ramos, V.A., 1986, El granito Archibarca: Su edad y significado tectónico, provincia de Catamarca: Revista de la Asociación Geológica Argentina, v. 41, p. 414-419.

Pankhurst, R.J., Rapela, C.W., Saavedra, J., Baldo, E.G., Dahlquist, J.A., Pascua, I., and Fanning, C.M., 1998, The Famatinian arc in the central Sierras Pampeanas: An Early to Mid-Ordovician continental arc on the Gondwana margin, in Pankhurst, R.J., and Rapela, C.W., eds., The Proto-Andean Margin of Gondwana: Geological Society of London Special Publication 142 p. 343-367, doi:10.1144/GSL.SP.1998.142.01.17.

Pankhurst, R.J., Rapela, C.W., and Fanning, C.M., 2000, Age and origin of coeval TTG, I-S-type granites in the Famatinian belt of NW Argentina: Transactions of the Royal Society of Edinburgh, Earth Sciences, v. 91, p. 151-168, doi:10.1017/S0263593300007343.

Plank, T., and Langmuir, C.H., 1998, The chemical composition of subducting sediment and its consequences for the crust and mantle: Chemical Geology, v. 145 , p. 325-394, doi:10.1016/S0009-2541(97)00150-2.

Pertermann, M., and Hirschmann, M.M., 2003, Partial melting experiments on a MORB-like pyroxenite between 2 and $3 \mathrm{GPa}$ : Constraints on the presence of pyroxenite in basalt source regions from solidus location and melting rate: Journal of Geophysical Research, v. 108, no. B2, p. 2125, doi: 10.1029/2000JB000118

Putirka, K., and Platt, B., 2012, Basin and Range volcanism as a passive response to extensional tectonics: Geosphere, v. 8, p. 1274-1285, doi:10.1130/GES00803.1.

Rapela, C.W., Pankhurst, R.J., Dahlquist, J.A., Baldo, E.G., Casquet, C., and Galindo, C., 2008, Revisiting accretionary history and magma sources in the southern Andes: Time variation of "typical Andean granites," in 7th International Symposium on Andean Geodynamics, Extended Abstracts: Nice, France, p. $427-430$.

Rapela, C.W., Verdecchia, S.O., Casquet, C., Pankhurst, R.J., Baldo, E.G., Galindo, C., Murra, J.A., Dahlquist, J.A., and Fanning, C.M., 2015, Identifying Laurentian and SW Gondwana sources in the Neoproterozoic to early Paleozoic metasedimentary rocks of the Sierras Pampeanas: Paleogeographic and tectonic implications: Gondwana Research, v. 32, p. 193-212, doi:10 .1016/j.gr.2015.02.010

Saavedra, J., Pellitero, E., Rossi, J., and Toselli, A., 1992 Magmatic evolution of the Cerro Toro granite, a complex Ordovician pluton of northwestern Argentina: Journal of South American Earth Sciences, v. 5, p. 2132, doi:10.1016/0895-9811(92)90057-6.

Saunders, A.D., and Tarney, J., 1984, Geochemical characteristics of basaltic volcanism within back-arc basins, in Kokelaar, B.P., and Howells, M.F., eds., Marginal Basin Geology: Geological Society of London Special Publication 16, p. 59-76, doi:10.1144/GSL.SP.1984 .016 .01 .05 .

Saunders, A.D., Norry, M.J., and Tarney, N.J., 1988, Origin of MORB and chemically-depleted mantle reservoirs Trace element constraints: Journal of Petrology, Special Volume, v. 1, p. 415-445, doi:10.1093/petrology /Special_Volume.1.415.

Sharp, Z.D., 1990, A laser-based microanalytical method for in situ determination of oxygen isotope ratios of silicates and oxides: Geochimica et Cosmochimica Acta, v. 54, p. 1353-1357, doi:10.1016/0016-7037 (90)90160-M.

Steiger, R.H., and Jäger, E., 1977, Subcommission of Geochronology: Convention on the use of decay constants in geo- and cosmochronology: Earth and Planetary Science Letters, v. 1, p. 369-371, doi:10.1016/0012-821X (77)90060-7.

Taylor, S.R., and McLennan, S.M., 1985, The Continental Crust: Its Composition and Evolution: Boston, Massachusetts, Blackwell Scientific, $312 \mathrm{p}$

Tibaldi, A.M., Otamendi, J.E., Cristofolini, E.A., Baliani, I., Walker, B.J., Jr., and Bergantz, G.W., 2013, Reconstruction of the Early Ordovician Famatinian arc through thermobarometry in lower and middle crustal exposures, Sierra de Valle Fértil, Argentina: Tectonophysics, v. 589, p. 151-166, doi:10.1016/j.tecto.2012 .12.032.

Toselli, A.J., Rossi de Toselli, J.N., Saavedra, J., Pellitero, E., and Medina, M.E., 1988, Aspectos petrológicos y geoquímicos de los granitoides del entorno de Villa Castelli, Sierras Pampeanas Occidentales-Sistema de Famatina, in 5th Congreso Geológico Chileno: Santiago, Chile, no. 3, p. I17-I28.

van Westrenen, W., Blundy, J.D., and Wood, B.J., 2011, High field strength element/rare earth element fractionation during partial melting in the presence of garnet: Implications for identification of mantle heterogeneities: Geochemistry Geophysics Geosystems, v. 2, p. 1039, doi:10.1029/2000GC000133.

Varela, R., Sato, A.M., Basei, M.A.S., and Siga, O., Jr., 2003, Proterozoico medio y Paleozoico inferior de la Sierra de Umango, Antepaís Andino $\left(29^{\circ} \mathrm{S}\right)$, Argentina. Edades $\mathrm{U} / \mathrm{Pb}$ y caracterizaciones isotópicas: Revista Geológica de Chile, v. 30, p. 265-284.

Verdecchia, S.O., Murra, J.A., Baldo, E.G., Casquet, C., Pascua, I., and Saavedra, J., 2014, Geoquímica de las rocas metasedimentarias del Cámbrico medio al Ordovícico temprano de la Sierra de Los Llanos (Sierras Pampeanas, Argentina): Fuente de sedimentos, correlación y ambiente geotectónico: Andean Geology, v. 41, p. 380-400, doi:10.5027/andgeoV41n2-a06.

SCIENCE Editor: Christian KoEberL

Associate Editor: SANDRA M. BARR

Manuscript Received 28 August 2015

Revised Manuscript Received 27 January 2016

ManUsCript Accepted 1 March 2016

Printed in the USA 


\title{
Geological Society of America Bulletin
}

\section{Mafic rocks of the Ordovician Famatinian magmatic arc (NW Argentina): New insights into the mantle contribution}

\author{
P.H. Alasino, C. Casquet, R.J. Pankhurst, C.W. Rapela, J.A. Dahlquist, C. Galindo, M.A. Larrovere, \\ C. Recio, S.R. Paterson, F. Colombo and E.G. Baldo
}

Geological Society of America Bulletin published online 20 April 2016; doi: 10.1130/B31417.1

\section{Email alerting services}

Subscribe

Permission request click www.gsapubs.org/cgi/alerts to receive free e-mail alerts when new articles cite this article

click www.gsapubs.org/subscriptions/ to subscribe to Geological Society of America Bulletin

click http://www.geosociety.org/pubs/copyrt.htm\#gsa to contact GSA

Copyright not claimed on content prepared wholly by U.S. government employees within scope of their employment. Individual scientists are hereby granted permission, without fees or further requests to GSA, to use a single figure, a single table, and/or a brief paragraph of text in subsequent works and to make unlimited copies of items in GSA's journals for noncommercial use in classrooms to further education and science. This file may not be posted to any Web site, but authors may post the abstracts only of their articles on their own or their organization's Web site providing the posting includes a reference to the article's full citation. GSA provides this and other forums for the presentation of diverse opinions and positions by scientists worldwide, regardless of their race, citizenship, gender, religion, or political viewpoint. Opinions presented in this publication do not reflect official positions of the Society.

\section{Notes}

Advance online articles have been peer reviewed and accepted for publication but have not yet appeared in the paper journal (edited, typeset versions may be posted when available prior to final publication). Advance online articles are citable and establish publication priority; they are indexed by GeoRef from initial publication. Citations to Advance online articles must include the digital object identifier (DOIs) and date of initial publication.

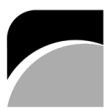

THE GEOLOGICAL SOCIETY OF AMERICA 